\title{
NAVIGANT
}

\section{RESEARCH AND DEVELOPMENT ROADMAP FOR WATER HEATING TECHNOLOGIES}

Prepared for:

Oak Ridge National Laboratory

Subcontract Number 4000093134

September 30, 2011

Navigant Consulting, Inc.

77 S. Bedford Street

Suite 400

Burlington, MA 01803

www.navigant.com

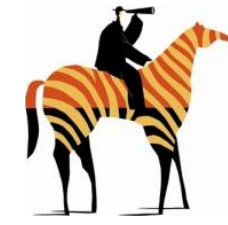




\section{Table of Contents}

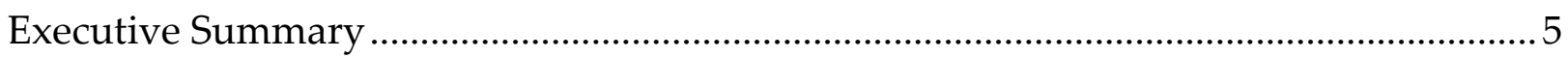

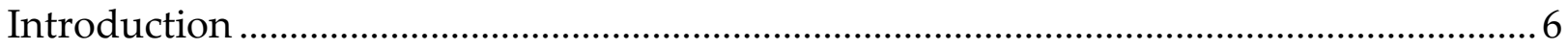

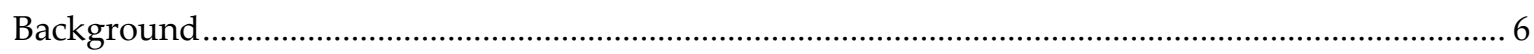

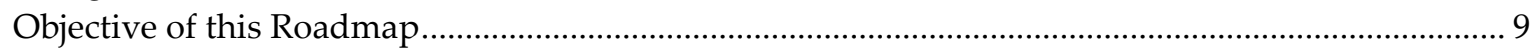

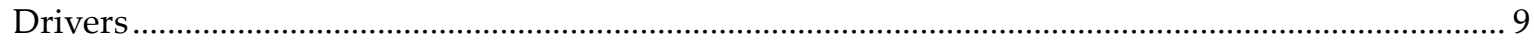

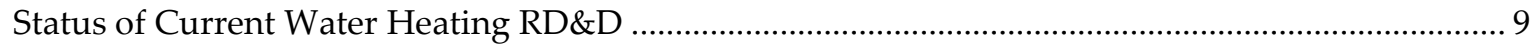

BTP has also identified several focus areas for the water heating RD\&D effort in the near-term:... 10

Roadmap Development Process ................................................................................................ 11

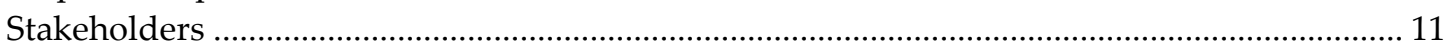

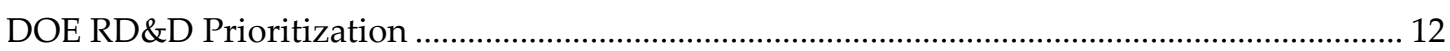

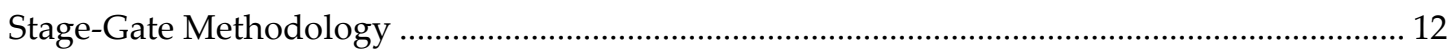

Current State of the Market ............................................................................................... 14

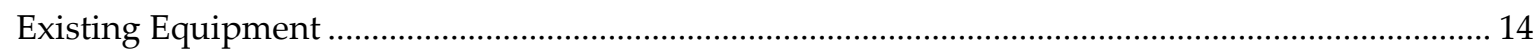

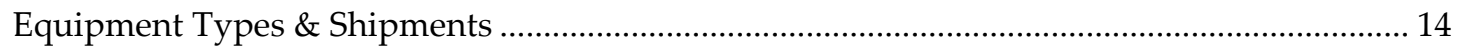

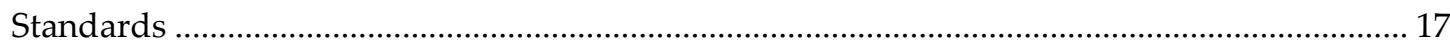

Market and Technical Challenges and Barriers ............................................................................ 19

Strategies for Overcoming Market and Technical Challenges and Barriers ...................................... 21

Research and Development Roadmap.................................................................... 23

Near-Term Technology Options -Years 2012-2019 Time Horizon ..................................................... 23

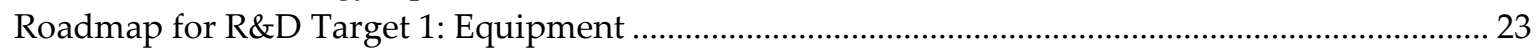

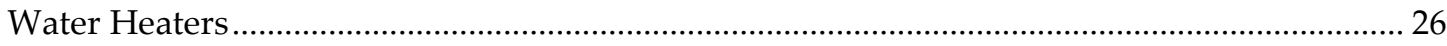

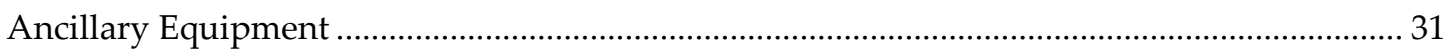

Roadmap for R\&D Target 2: System Design, Operation, and Maintenance....................................... 31

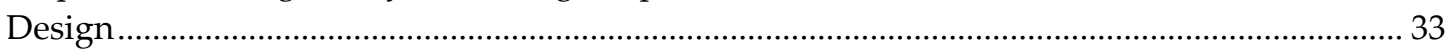

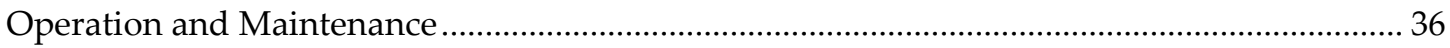

Roadmap for R\&D Target 3: Policy and Markets .............................................................................. 38

Appendix - Stakeholder Workshop …................................................................... 1 


\section{List of Figures}

Figure 1. 2010 U.S. Buildings Energy End-Use Splits, Total 40.40 Quads 7

Figure 2. Residential Buildings Energy Use by End Use, Total 22.05 Quads ............................................. 8

Figure 3. Commercial Buildings Energy Use by End Use. Total 18.35 Quads ............................................. 8

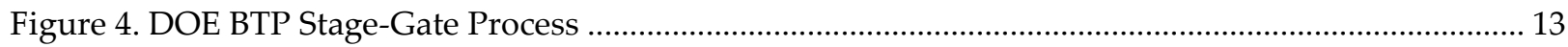

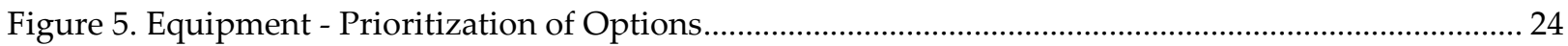

Figure 6. Timelines \& Priorities for R\&D Target 1: Equipment ............................................................ 25

Figure 7. Work Breakdown Structure for Gas Powered HPWH................................................................. 28

Figure 8. Work Breakdown Structure for Advanced Electric HPWH .......................................................... 29

Figure 9. Design, Operation \& Maintenance - Prioritization of Options ...................................................... 32

Figure 10. Timelines \& Priorities for R\&D Target 2: Design, Operation \& Maintenance ............................. 33

Figure 11. Work Breakdown Structure for Study of Existing Water Heating Systems................................. 35

Figure 12. Work Breakdown Structure for Development of Low-Cost Auditing Tools.............................. 37

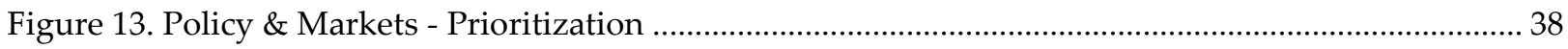

Figure 14. Timelines \& Priorities for R\&D Target 3: Policy \& Markets.......................................................... 39 


\section{List of Tables}

Table 1. RD\&D Examples for Next-Generation Water Heating Technologies 10

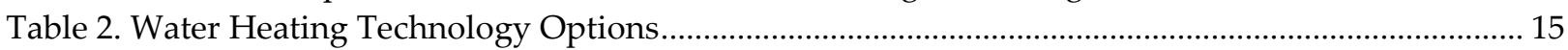

Table 3. Breakdown of Residential Water Heating System Shipments.................................................. 16

Table 4. Breakdown of Commercial Water Heating System Shipments ....................................................... 16

Table 5. DOE Mandatory Minimum Efficiency Standards …....................................................................... 18

Table 6. ENERGY STAR Specifications and Qualifying Models................................................................. 19

Table 7. Water Heating - Challenges and Barriers ..................................................................................... 20

Table 8. Water Heating Strategies for Overcoming Market and Technical Barriers and Challenges ......... 22

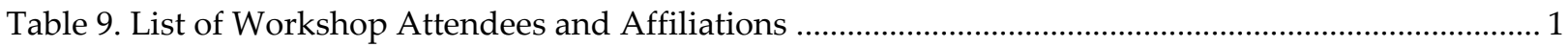

Table 10. Ideas Proposed During Water Heating Workshop …..................................................................... 1 
List of Acronyms

$\begin{array}{ll}\text { A/C } & \text { Air-Conditioning } \\ \text { ACEEE } & \text { American Council for an Energy-Efficient Economy } \\ \text { ASHRAE } & \text { American Society of Heating, Refrigeration, and Air-Conditioning Engineers } \\ \text { BTP } & \text { Building Technologies Program (Department of Energy) } \\ \text { CEE } & \text { Consortium for Energy Efficiency } \\ \text { CO}_{2} & \text { Carbon Dioxide } \\ \text { DOE } & \text { Department of Energy } \\ \text { EF } & \text { Energy Factor } \\ \text { EPA } & \text { Environmental Protection Agency } \\ \text { FEMP } & \text { Federal Energy Management Program } \\ \text { GHG } & \text { Greenhouse Gas } \\ \text { GWP } & \text { Global Warming Potential } \\ \text { HVAC } & \text { Heating, Ventilation, and Air-Conditioning } \\ \text { HPWH } & \text { Heat Pump Water Heater } \\ \text { LEED } & \text { Leadership in Energy and Environmental Design } \\ \text { LBNL } & \text { Lawrence Berkeley National Laboratory } \\ \text { MYPPs } & \text { Multiyear Program Plans } \\ \text { NREL } & \text { National Renewable Energy Laboratory } \\ \text { ORNL } & \text { Oak Ridge National Laboratory } \\ \text { PNNL } & \text { Pacific Northwest National Laboratory } \\ \text { POU } & \text { Point-of-Use } \\ \text { SWH } & \text { Solar Water Heating/Heater } \\ & \end{array}$




\section{NAVIGANT}

Executive Summary

Although water heating is an important energy end-use in residential and commercial buildings, efficiency improvements in recent years have been relatively modest. However, significant advancements related to higher efficiency equipment, as well as improved distribution systems, are now viable. DOE support for water heating research, development and demonstration (RD\&D) could provide the impetus for commercialization of these advancements.

Existing water heating equipment is primarily comprised of fuel-fired or electric storage water heaters. Some higher efficiency options exist for gas and electric units, but their market penetration is low. The ENERGY STAR program for residential water heaters, which began in 2009, is expected to contribute significantly to the adoption of higher efficiency models such as condensing gas storage, condensing gas tankless, heat pump water heaters, and solar water heaters. However, none of the existing, commercialized technologies is sufficient to enable true market transformation. For equipment, more advanced and higher efficiency options must be developed and deployed at reasonable price points. For example, electric heat pump water heaters have already been introduced, but dramatically higher efficiencies are technically feasible. Gas-fired heat pump water heaters have been demonstrated to be technically feasible, but are not yet commercialized.

Water heater equipment, however, is but one dimension of the solution. The hot water distribution system and its usage patterns can have a significant impact on the amount of energy and water consumed. The distribution system - which includes operation and maintenance as well as system design - must be better understood. Savings from distribution system optimization appear to be significant, but best practices and designs for distribution systems are not yet well defined, because these elements have not been sufficiently analyzed.

This roadmap establishes a set of high-priority RD\&D activities for water heating systems. The proposed activities address the major unfulfilled needs regarding the latest equipment and equipment-related advancements, critical gaps in knowledge and tools related to efficient distribution systems, and market transformation activities related to these areas. The schedule of R\&D activities occurs within a sevenyear timeframe, beginning with Fiscal Year 2012, to accelerate advancements that might otherwise take much longer to be realized. 


\section{Introduction}

\section{Background}

Modest improvements to the efficiency of water heaters have occurred over the last two decades, in large part because of the minimum efficiency standards that were implemented in 1990 and increased in 2004. Another increase in the minimum standards is scheduled to occur in April 2015, and will again bring a moderate increase to the baseline efficiency of the stock of residential and commercial water heaters. For the most part, however, the water heater industry has experienced little change-even the physical form of the equipment is largely the same.

Uptake of high efficiency products has been slow although ENERGY STAR for residential water heaters, introduced in 2009, is expected to help in this regard. Dramatic reductions in the energy use of water heaters will require the development of next generation technologies and successful deployment of those technologies across the water heating market.

In 2010, water heating represented approximately $9.1 \%$ (or approximately 3.7 quads) of the total energy used by all buildings in the United States (Figure 1). Water heating is the fourth largest energy end-use in the U.S. building stock.

In residential buildings, water heating was responsible for approximately 2.9 quads, or $13.2 \%$, of total energy consumption (Figure 2), and is the third largest energy end-use after space heating and cooling. Commercial building water heating consumed approximately 0.8 quads or about $4.3 \%$ of the total energy used by the commercial sector (Figure 3). Although lower in total than the water heating energy use in the residential market, commercial water heating is concentrated in just a few building types. Hotels, hospitals, and food service together represent over $75 \%$ of the commercial sector's water heating energy use. ${ }^{1}$

Most of the focus on water heating revolves around equipment, however, the distribution system of a home or building has a significant and enduring impact on how much hot water is heated to supply a given demand. Altogether, water use in residential and commercial buildings accounted for about $10 \%$ of all U.S. water use in 2005-nearly 40 billion gallons of water per day - with the residential sector using about three-quarters of the total for all buildings. ${ }^{2}$ A large portion of total water use is hot water; a limited survey of homes in the Northwest indicated that hot water use accounted for approximately $40 \%$ of total residential water use. ${ }^{3}$ Furthermore, distribution losses are estimated to account for about $5 \%$ of hot water use in U.S. homes. ${ }^{4}$

Likewise, the behavior of a building's occupants is a significant determinant of total water use and hot water demand. A recent pilot study conducted in California indicates that as much as $40 \%$ of the hot

\footnotetext{
12010 Buildings Energy Data Book

22010 Buildings Energy Data Book, Table 8.1.1

${ }^{3} 2010$ Buildings Energy Data Book, Table 8.2.4

${ }^{4} 2010$ Buildings Energy Data Book, Tables 8.2.3 and 8.2.4
} 
water consumed for a typical shower may be wasted (run down the drain) while waiting on the water temperature out of the shower head to reach a comfortable temperature. ${ }^{5}$

Figure 1. 2010 U.S. Buildings Energy End-Use Splits, Total 40.40 Quads $^{6}$

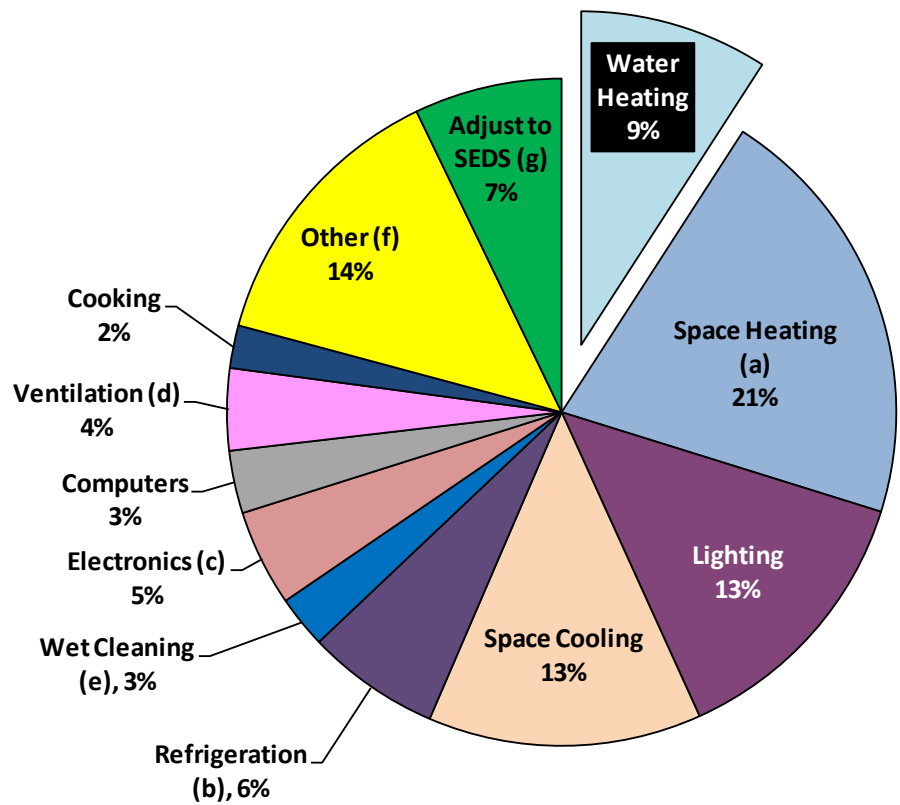

\footnotetext{
${ }^{5}$ Lutz, J, "Water and Energy Wasted During Residential Shower Events: Findings from a Pilot Field Study of Hot Water Distribution Systems", ASHRAE, January 2012.

${ }^{6}$ Source: 2010 Buildings Energy Data Book, (a) Includes furnace fans (0.14 quad); (b) Includes refrigerators (2.37 quad) and freezers (0.25 quad). Includes commercial refrigeration; (c) Includes color television (1.07 quad);. (d) Commercial only; residential fan and pump energy use included proportionately in space heating and cooling; (e) Includes clothes washers ( 0.10 quad), natural gas clothes dryers (0.05 quad), electric clothes dryers ( 0.58 quad), and dishwashers (0.28 quad). Does not include water heating energy; (f) Includes residential small electric devices, heating elements, motors, swimming pool heaters, hot tub heaters, outdoor grills, and natural gas outdoor lighting. Includes commercial service station equipment, ATMs, telecommunications equipment, medical equipment, pumps, emergency electric generators, combined heat and power in commercial buildings, and manufacturing performed in commercial buildings; (g) Energy adjustment the Energy Information Administration ( EIA) uses to relieve discrepancies between data sources. Energy attributable to the residential and commercial buildings sector, but not directly to specific end uses.
} 


\section{NAVIGANT}

Figure 2. Residential Buildings Energy Use by End Use, Total 22.05 Quads

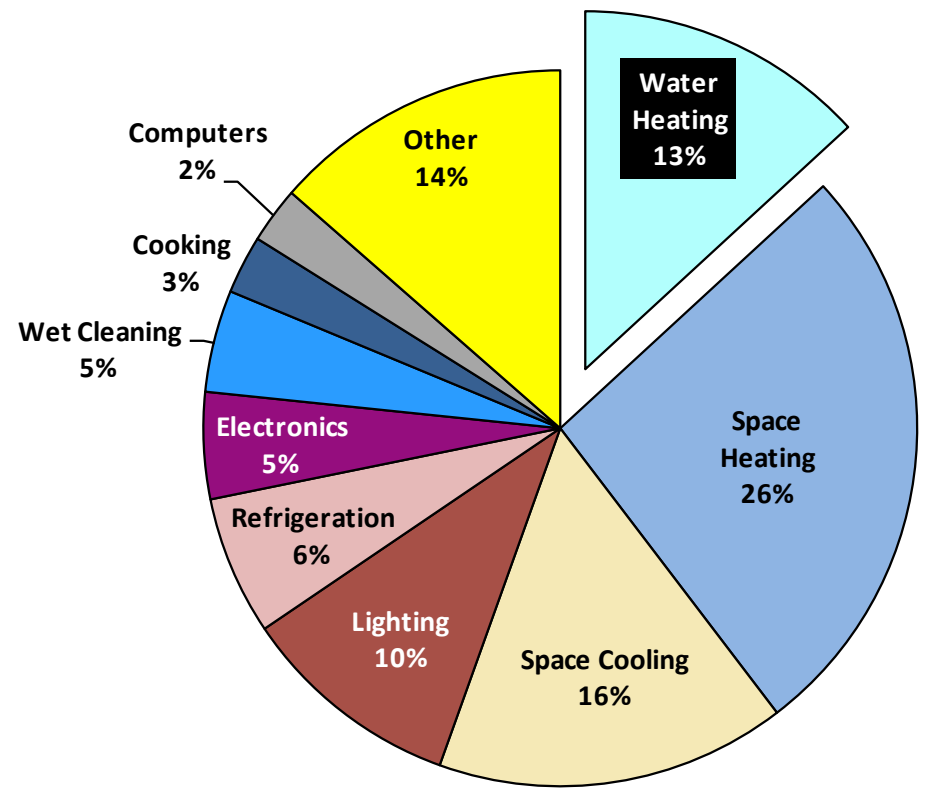

Figure 3. Commercial Buildings Energy Use by End Use. Total 18.35 Quads

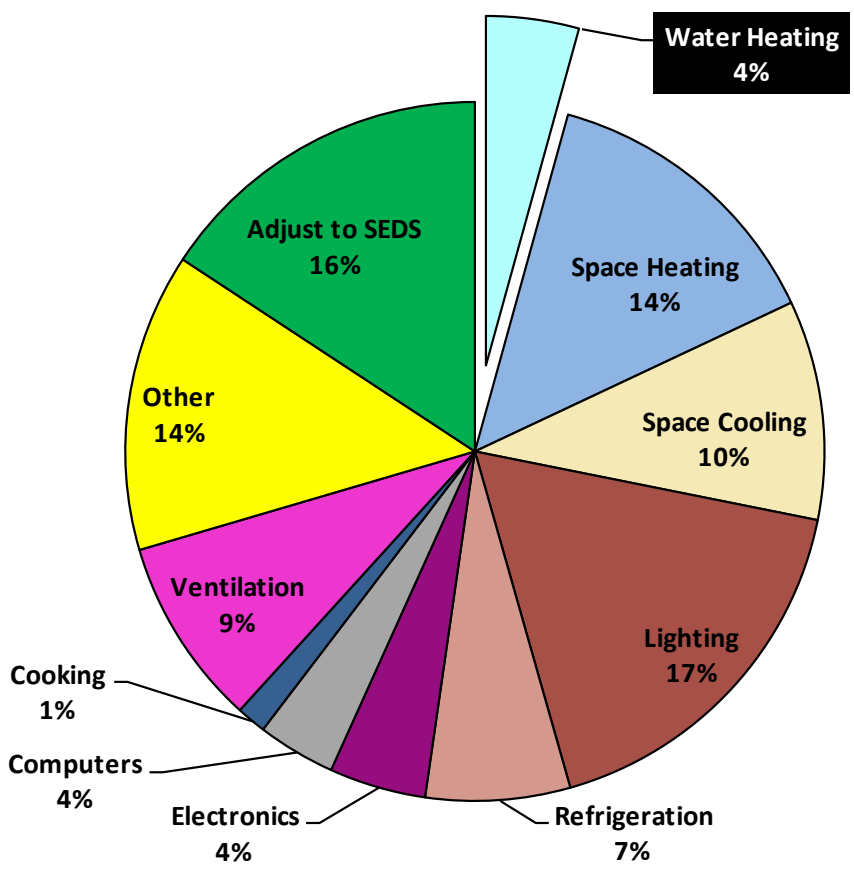

${ }^{7} 2010$ Buildings Energy Data Book 


\section{NAVIGANT}

\section{Objective of this Roadmap}

This roadmap lays out a strategy for the U.S. Department of Energy (DOE) Buildings Technologies Program (BTP) Water Heating Research and Development (R\&D) program to help DOE meet near- and long-term goals for energy use and carbon emissions reductions. The roadmap provides a guide for developing DOE BTP's Multiyear Program Plans (MYPPs), as well as for developing R\&D solicitations for its water heating R\&D activities. The expectation is that this roadmap will be reviewed on an ongoing basis by DOE and its industry partners, and updated to reflect progress toward and priorities for achieving the ultimate goals of the program.

This roadmap focuses on identifying R\&D opportunities for DOE to pursue in the near-term (2012-2019 time frame). The roadmap is organized around three main areas of focus:

- Equipment, including water heaters and ancillary devices

- System design, including hot water distribution systems and design tools

- Policy and markets, including codes/standards and test methods, market encouragement and facilitation activities, etc.

\section{Drivers}

The Department of Energy's Strategic Plan provides DOE's mission as “ensuring America's security and prosperity by addressing its energy, environmental, and nuclear challenges through transformative science and technology solutions." 8 Buildings are responsible for approximately $40 \%$ of U.S. energy use and carbon emissions, and are thus a critical piece of the energy and environmental challenge identified in DOE's Strategic Plan. ${ }^{9}$

BTP's central vision is to significantly improve the efficiency of existing and new buildings through the development of conservation technologies, strategies, and practices. The strategic goal focuses on developing cost-effective solutions that enable adoption in the marketplace. ${ }^{10} \mathrm{BTP}$ supports DOE's objectives by developing and promoting "technologies, techniques, and tools for making residential and commercial buildings more energy efficient, productive and affordable... [through] research, development, demonstration, and deployment activities in partnership with industry, government agencies, universities, and national laboratories."11 As a major energy end-use in buildings, water heating energy consumption is a natural target of BTP's efforts.

\section{Status of Current Water Heating RDED}

Current residential water heating R\&D efforts focus on technologies, products, and solutions that support energy use reduction in buildings, and are fully aligned with the strategic goals of the DOE BTP program.

BTP's current strategy emphasizes the importance of developing technologies and system-level strategies for new and retrofit applications in the residential and commercial sectors. BTP addresses

${ }^{8}$ DOE Strategic Plan, May 2011, page v.

${ }_{9}^{9} 2010$ Buildings Energy Data Book

${ }^{10}$ DOE Building Technologies Program Vision \& Mission, http://www1.eere.energy.gov/buildings/vision.html

${ }^{11}$ DOE Building Technologies Program Vision \& Mission, http://www1.eere.energy.gov/buildings/vision.html 


\section{NAVIGANT}

water heating R\&D through its Emerging Technologies subprogram, specifically the Space Conditioning $R \& D$ activity. The Space Conditioning R\&D activity plans to reduce residential water heating energy consumption by $80 \%$ over baseline levels by 2020 . Examples of current R\&D efforts in progress through DOE and its laboratories can be found in Table 1.

Table 1. RD\&D Examples for Next-Generation Water Heating Technologies

\begin{tabular}{ll}
$\begin{array}{l}\text { Technology } \\
\text { Absorption Heat Pump Water } \\
\text { Heater12 }\end{array}$ & $\begin{array}{l}\text { Description } \\
\text { In 2010, ORNL patented and began licensing an absorption heat pump water heater } \\
\text { (HPWH) technology for residential and commercial water heating applications. The } \\
\text { system uses a lithium bromide absorption cycle and offers significant energy savings } \\
\text { over standard water heaters. Stone Mountain Technologies is developing a gas-fired } \\
\text { absorption water heater based on the ammonia-water absorption cycle. }{ }^{13}\end{array}$ \\
$\begin{array}{ll}\text { Heat Pump Water Heater with } \mathrm{CO}_{2} \\
\text { Refrigerant }\end{array}$ & $\begin{array}{l}\text { ORNL is developing a heat pump water heater with } \mathrm{CO}_{2} \text { refrigerant for the U.S. } \\
\text { market. This technology is commercialized in Japan under the brand name EcoCute, } \\
\text { and over one million units have been sold. The ORNL project seeks to adapt the } \\
\text { technology for the U.S. market. A commercial version of a CO } \text { HPWH is under }\end{array}$ \\
$\begin{array}{l}\text { development by Creative Thermal Solutions, with DOE support. } \\
\text { Air Source and Ground Source } \\
\text { Integrated Heat Pump }\end{array}$ & $\begin{array}{l}\text { These combined HVAC/water heating units are currently being field-tested in } \\
\text { Tennessee by ORNL for residential markets. }\end{array}$ \\
\hline $\begin{array}{l}\text { ZigBee Standard Wireless } \\
\text { Controller }\end{array}$ & $\begin{array}{l}\text { This product incorporates a predictive algorithm that learns usage patterns and } \\
\text { reduces unnecessary water heating during times of peak grid usage. It can also track } \\
\text { grid-load patterns via its communication link to the Smart Grid. The product will also } \\
\text { include an interactive user display enabling the consumer to manage the cost and } \\
\text { energy used by the water heater. }\end{array}$ \\
\hline
\end{tabular}

BTP has also identified several focus areas for the water heating RD\&D effort in the near-term:

- Assess novel methods of integrating highly efficient space conditioning and water heating equipment

- Investigate affordable advanced materials, components, refrigeration cycles, and systems, to improve system energy consumption (includes $\mathrm{CO}_{2}$ systems).

- Develop retrofit technologies

- Develop reliable, multi-functional next-generation residential water heaters at a cost effective price premium

- Develop low global warming potential refrigerants

- Continue development of next generation working fluids, refrigerants and blowing agents

The roadmap process identified specific research areas and projects for DOE BTP to consider for nearand medium-term RD\&D projects going forward. Throughout the roadmap process and especially during the stakeholder workshop, a number of ideas related to solar water heating were suggested and discussed. Solar options are considered briefly in this document and will be considered in greater detail in a separate $R \& D$ roadmap on solar water heating.

\footnotetext{
${ }^{12}$ http://www.ornl.gov/adm/partnerships/factsheets/10-G01078 ID2389.pdf

${ }^{13}$ http://www1.eere.energy.gov/recovery/pdfs/btp arra selections combined.pdf
} 


\section{NAVIGANT}

To ensure that water heating RD\&D activities remain aligned with DOE's strategic goals as they evolve, BTP will ensure that its other subprograms are involved through periodic meetings, research collaboration, and participation in program review meetings. In particular, the Heating, Ventilating, and Air Conditioning, Water Heating, and Working Fluids subprograms will work closely with BTP's Residential Integration subprogram through periodic meetings, research collaboration, and participation in their program review meetings. BTP's Residential Integration subprogram develops business models and works to decrease the cost of home energy retrofits, improve the transparency of energy efficiency improvements, and develop a trained workforce to reduce market barriers and increase market penetrations of retrofits.

The Commercial Integration team is targeting 70\% energy use reductions in commercial buildings by 2025. They have begun to identify the water heating system and equipment performance needs to support these goals. The Emerging Technologies subprogram will continue to work closely with the Commercial Integration team to understand their needs, develop solutions, and test the resulting systems.

\section{Roadmap Development Process}

This R\&D roadmap was developed by Navigant Consulting, Inc. and the roadmap development team \{Oak Ridge National Laboratory (ORNL) - lead, Lawrence Berkeley National Laboratory (LBNL), National Renewable Energy Laboratory (NREL), and Pacific Northwest National Laboratory (PNNL)\} on behalf of DOE BTP.

Developing this roadmap was a multistep process that included identifying and evaluating potential areas of research, a stakeholder workshop to discuss potential research areas, gather ideas, and understand stakeholder priorities, and additional evaluation of potential research areas against DOE priorities. The process culminated in the publication of this roadmap, although it is expected that the roadmap will be updated on an ongoing basis.

\section{Stakeholders}

DOE has undertaken several successful roadmap efforts in recent years including the 2005 Solar and Efficient Water Heating Roadmap, the National Combined Heat and Power Roadmap ${ }^{14}$, the Solid-State Lighting Research and Development Roadmap ${ }^{15}$, the HVAC Roadmap (under development), and the Next Generation Refrigerants Roadmap. These roadmaps have been successful in defining and implementing research and development activities that will lead to significant energy savings, and a key ingredient in these successes was participation from industry, utilities, academia, associations, and other stakeholders during the development of the roadmaps.

On May 9 and 10, 2011, DOE BTP hosted a stakeholder workshop to identify and vet water heating research, development, and demonstration priorities for the water heating industry. The workshop was held in Berkeley, California, in conjunction with the annual Hot Water Forum hosted by the American

\footnotetext{
${ }^{14}$ United States Combined Heat \& Power Association, U.S. DOE and U.S. EPA, National CHP Roadmap: Doubling Combined Heat and Power Capacity in the United States by 2010, 2001.

${ }^{15}$ U.S. DOE, Office of Energy Efficiency \& Renewable Energy, Solid-State Lighting Research and Development Manufacturing Roadmap, July 2011.
} 
Council for an Energy-Efficient Economy (ACEEE). Ninety participants attended the workshop, including representatives from water heating equipment manufacturers, utilities, industry trade groups and organizations, government, DOE laboratories, and other research institutions.

Participants in the stakeholder workshop identified numerous potential RD\&D activities for DOE and other actors and voted on their priority RD\&D ideas at the conclusion of the workshop. Appendix A provides a summary of the workshop, a list of participants and their affiliations, and a list of the ideas and voting results generated through the workshop.

\section{DOE RD\&D Prioritization}

In addition to stakeholder input, issues related to the appropriateness of government support, fit with overall DOE BTP priorities, and likelihood of technical and market success as well as commercialization opportunity were considered in the process of selecting priorities for inclusion in this roadmap.

\section{Stage-Gate Methodology}

DOE BTP uses a modified Stage-Gate process to reduce risk when identifying potential RD\&D projects. The BTP-adapted Stage-Gate methodology (Figure 4) involves several gates and stages. Ideas are successively screened through Gate 1 to Gate 7 to reach the feasibility stage, scoping stage, business case stage, conceptual design stage, lab prototype stage, and, finally, the field prototype stage. In order to pass through each stage, an idea is evaluated on "must-meet" criteria, which are required in order for the project to pass into the next stage, as well as "should meet" criteria, which are desirable but not mandatory.

Although there is a potential federal role through all stages and gates, the greatest opportunities for eventual successful transition to the market come with significant private-sector (especially manufacturer) collaboration. Partnerships with appropriate private-sector entities will be pursued at the earliest possible stage, so that technology and product development efforts are complementary rather than duplicative. 
Figure 4. DOE BTP Stage-Gate Process

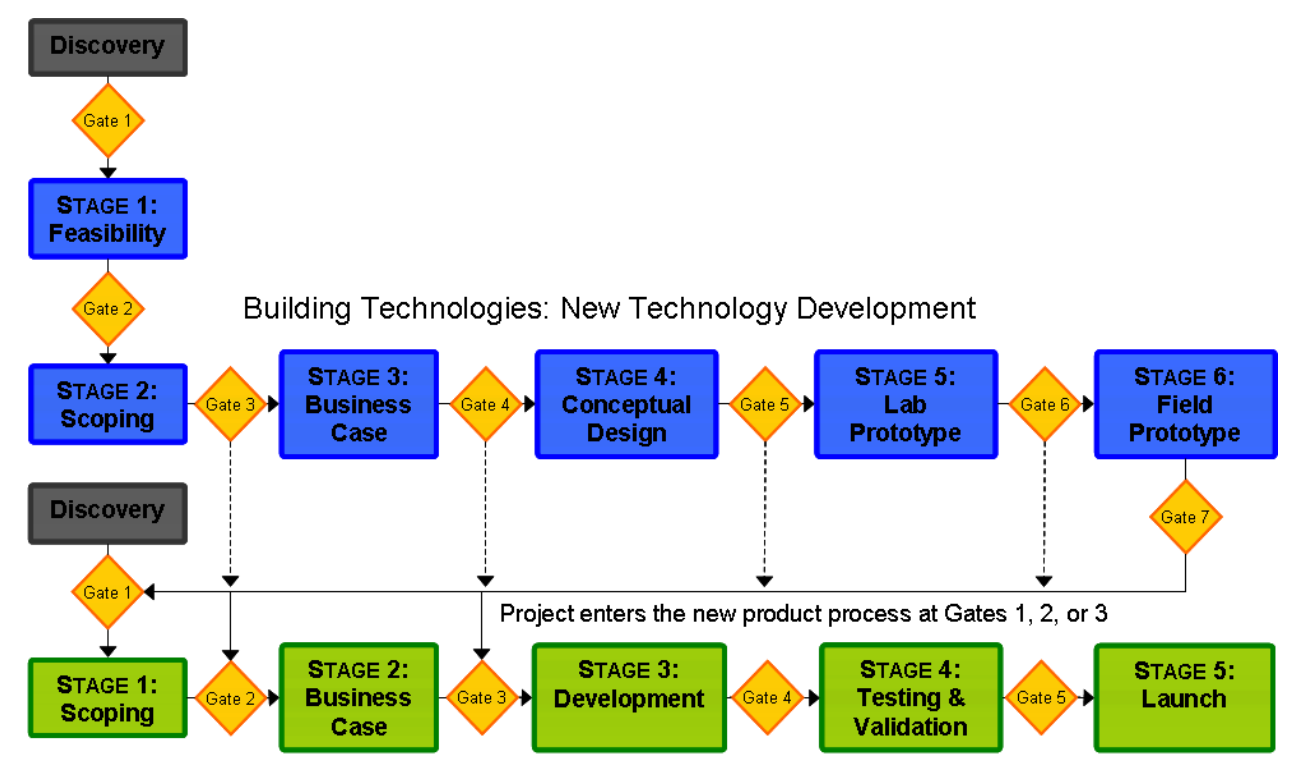

Private Sector: New Product Development 


\section{Current State of the Market}

The following section describes the current market for water heaters in the United States, including a review of existing equipment, equipment standards and shipments, and challenges to increasing the adoption of high efficiency equipment.

\section{Existing Equipment}

This section describes the types of equipment available in the United States, minimum performance standards and ENERGY STAR standards, and shipments data.

Equipment Types \& Shipments

The U.S. water heating market offers residential and commercial consumers several distinct technology options (Table 2). 
Table 2. Water Heating Technology Options

\begin{tabular}{|c|c|c|c|}
\hline Fuel & \multicolumn{2}{|c|}{ Technology } & Description \\
\hline \multirow[t]{6}{*}{ Fuel-fired } & \multirow[t]{3}{*}{ Storage } & Standard & Heat loss occurs primarily through flue gases and stand-by. \\
\hline & & HE Standard & $\begin{array}{l}\text { Better insulation, heat traps and burners, and, in some cases, a power } \\
\text { vent or flue damper. }\end{array}$ \\
\hline & & Condensing & Captures the latent heat of combustion gases before they exit the tank. \\
\hline & \multirow{2}{*}{ Tankless } & Standard & Heats water in a continuous flow process, eliminating standby losses. \\
\hline & & Condensing & $\begin{array}{l}\text { Eliminates stand-by losses, increases efficiency with secondary heat } \\
\text { exchanger. }\end{array}$ \\
\hline & Hybrid & & $\begin{array}{l}\text { Gas tankless water heater with small ( } \leq 20 \text { gallons) storage tank. } \\
\text { Stored hot water reduces wait time that may occur with a tankless } \\
\text { heater as it fires up, yet preserves most of the efficiency benefit from } \\
\text { low stand-by losses. }\end{array}$ \\
\hline \multirow[t]{4}{*}{ Electric } & \multicolumn{2}{|l|}{ Standard } & Heats water through two electric elements within the storage tank. \\
\hline & \multicolumn{2}{|l|}{ Tankless } & $\begin{array}{l}\text { Heats water in a continuous flow process using electric heating } \\
\text { elements. }\end{array}$ \\
\hline & \multicolumn{2}{|c|}{ HE Standard } & $\begin{array}{l}\text { A more efficient version of the Standard model due to insulation and } \\
\text { thermal improvements. }\end{array}$ \\
\hline & \multicolumn{2}{|c|}{$\begin{array}{l}\text { Heat Pump } \\
\text { Water Heater }\end{array}$} & $\begin{array}{l}\text { Electric heat pump water heaters extract low-grade heat from the air } \\
\text { and transfer this heat to water. Heat pump water heaters can be } \\
\text { integrated models that fully replace standard electric water heaters or } \\
\text { can be add-on units added to existing electric or gas storage water } \\
\text { heaters. }\end{array}$ \\
\hline \multirow[t]{2}{*}{ Any } & \multicolumn{2}{|c|}{ Solar with Back-up } & $\begin{array}{l}\text { Solar water heaters use captured solar thermal energy to heat water in } \\
\text { a storage tank. SWH systems may be direct (uses water from the main) } \\
\text { or indirect (uses a working fluid), active (electric pump) or passive. SWH } \\
\text { systems can be backed up with a grid-tied gas or electric water heater. }\end{array}$ \\
\hline & \multicolumn{2}{|c|}{ Drain Water Heat Recovery } & $\begin{array}{l}\text { Recovers heat from drain water and transfers to incoming cold water } \\
\text { stream. Efficiency requirements do not exist in the U.S. but vary from } \\
30-42 \% \text { elsewhere. }\end{array}$ \\
\hline
\end{tabular}

The most prevalent options are gas-fired and electric resistance models with attached storage tanks. Tank-type models currently represent $95 \%$ of sales in the residential market. Tankless models are relatively new entrants to the market but are gaining market acceptance and currently represent roughly $5 \%$ of total sales, the vast majority of which are EnergyStar qualified gas tankless models. All other water heater types-including heat pump water heaters, an alternative to electric resistance models; solar water heaters, which use thermal energy from the sun to heat water; and drain water heat recovery, which captures heat from water as it flows down the drain-capture a small fraction of the market. ${ }^{16}$ Heat pump water heaters, a new entrant to the water heating market are still a very small portion of the overall sales of electric storage units but appear to be taking off (heat pumps represented approximately $1.6 \%$ of the market in 2010 versus $0.4 \%$ of the market in 2009).

${ }^{16}$ ENERGY STAR Water Heater Market Profile, 2010 
Table 3. Breakdown of Residential Water Heating System Shipments

\begin{tabular}{|c|c|c|}
\hline Residential & 2009 & 2010 \\
\hline Gas Storage (Total) & $3,760,657$ & $3,918,510$ \\
\hline Not $E^{* 17}$ & $3,110,419$ & $3,463,780$ \\
\hline$E^{*}$-qualifying ${ }^{18}$ & 650,238 & 454,730 \\
\hline Gas Tankless (Total) ${ }^{19}$ & 380,000 & $399,000^{20}$ \\
\hline Not $E^{*}$ & 46,987 & 14,974 \\
\hline$E^{*}$-qualifying & 333,013 & 384,026 \\
\hline Electric Storage (Total) & $3,751,994$ & $3,736,597$ \\
\hline Not $E^{\star 21}$ & $3,737,260$ & $3,677,472$ \\
\hline$E^{*}$-qualifying (heat pump) ${ }^{22}$ & 14,734 & 59,125 \\
\hline Solar 23 & 31,647 & 33,462 \\
\hline Not $E^{*}$ & 24,751 & 23,472 \\
\hline$E^{*}$-qualifying & 6,896 & 9,990 \\
\hline TOTAL & $7,924,298$ & $8,087,569$ \\
\hline Total Not $E^{*}$ & $6,919,417$ & $7,179,698$ \\
\hline Total $E^{*}$ qualifying & $1,004,881$ & 907,871 \\
\hline
\end{tabular}

Table 4. Breakdown of Commercial Water Heating System Shipments

\begin{tabular}{lcc} 
Commercial24 $^{24}$ & 2009 & 2010 \\
\hline Gas, storage & 75,487 & 78,614 \\
\hline Electric, storage & 55,625 & 58,349 \\
\hline \hline Total & 131,112 & 136,963 \\
\hline
\end{tabular}

Residential models dominate annual shipments of water heating equipment (Table 3 and Table 4). The residential installed base of water heaters is approximately 100 million units. With approximately 7 to $8 \%$ of these units requiring replacement in a given year, the vast majority of shipments go toward

\footnotetext{
${ }^{17}$ Air-Conditioning, Heating, and Refrigeration Institute (AHRI), AHRI December 2010 U.S. Heating and Cooling Equipment Shipment Data.

18 ENERGY STAR Product Type Market Share, Preliminary data for 2009 and 2010, U.S. EPA

${ }^{19}$ ENERGY STAR Product Type Market Share, Preliminary data for 2009 and 2010, U.S. EPA

${ }^{20}$ Data not available through ENERGY STAR or AHRI. Based on estimates provided by Mike Parker, A.O. Smith, Key note presentation at ACEEE Hot Water Forum, May 10, 2011.

${ }^{21}$ Air-Conditioning, Heating, and Refrigeration Institute (AHRI), AHRI December 2010 U.S. Heating and Cooling Equipment Shipment Data.

22 ENERGY STAR Product Type Market Share, Preliminary data for 2009 and 2010, U.S. EPA

23 Solar Energy Industries Association (SEIA), U.S. Solar Market Insight Year in Review 2010, March 2011.

${ }^{24}$ Air-Conditioning, Heating, and Refrigeration Institute (AHRI), AHRI December 2010 U.S. Heating and Cooling Equipment Shipment Data.
} 
replacing old units. The new construction market represents a much smaller portion of annual sales, and the economic downturn that began in 2008 slowed new construction sales..$^{25}$

An emerging trend in the residential market is an increase in sales of higher efficiency equipment. In 2009, one million units shipped (13\% of the market) were ENERGY STAR-qualified models of all types compared with just 625,000 high efficiency units (comparable to ENERGY STAR's 2009 qualifying levels) shipped in 2006, even more remarkable considering that the overall market shrank during that period. ${ }^{26}$ The ENERGY STAR program for residential water heaters launched in 2009 and well over a thousand qualifying models (gas storage, gas tankless, heat pump water heater, solar) have been registered through the program.

\section{Standards}

In 1987, Congress established efficiency standards for water heaters. DOE promulgates minimum energy efficiency standards for water heaters, which have been in effect since 1990. The most recent update to the standards took effect in 2004 and another increase is set to occur in 2015.

DOE's current and upcoming minimum efficiency standards can be found in Table 5. These minimum standards apply to residential and commercial units of all fuel and electric sources.

${ }^{25}$ ENERGY STAR Water Heater Market Profile, 2010

${ }^{26}$ Based on ENERGY STAR-qualifying equivalent models, ENERGY STAR Water Heater Market Profile, 2010 
Table 5. DOE Mandatory Minimum Efficiency Standards

\begin{tabular}{|c|c|c|c|c|}
\hline $\begin{array}{l}\text { Effective } \\
\text { Date }\end{array}$ & \multicolumn{2}{|c|}{ Product Type } & Minimum Efficiency & Product Specification \\
\hline \multirow[t]{4}{*}{ Existing } & \multirow[t]{3}{*}{ Storage } & Gas & $0.67-\left(0.0019 \times V^{* *}\right)$ & $\begin{array}{l}\text { Input Rating: } \\
20 \text { to } 100 \text { gal }\end{array}$ \\
\hline & & Oil & $0.59-(0.0019 \times \mathrm{V})$ & $\begin{array}{l}\text { Input Rating: } \leq 105,000 \text { Btu/hr AND Rated Storage: } \\
\leq 50 \text { gallons }\end{array}$ \\
\hline & & Electric & $0.97-(0.00132$ XV) & $\frac{\text { Input Rating: }}{120 \text { gallons }} \leq 12$ kW AND Rated Storage: 20 to \\
\hline & Tankless & Gas & $0.62-(0.0019 \times V)$ & $\begin{array}{l}\text { Input Rating: } 50,000 \mathrm{Btu} / \mathrm{hr} \text { to } 200,000 \mathrm{Btu} / \mathrm{hr} \text {; no } \\
\text { more than } 1 \text { gal water per } 4,000 \mathrm{Btu} / \mathrm{hr} \text { of input AND } \\
\text { Rated Storage: } \leq 2 \text { gal }\end{array}$ \\
\hline \multirow[t]{6}{*}{$\begin{array}{l}\text { As of April 16, } \\
2015\end{array}$} & \multirow[t]{5}{*}{ Storage } & \multirow[t]{2}{*}{ Gas } & $0.675-(0.0015 \times V)$ & $\frac{\text { Input Rating: }}{55 \text { gallons }} \leq 75,000$ Btu/hr AND Rated Storage: $\leq$ \\
\hline & & & $\begin{array}{l}0.8012-(0.00078 X \\
\text { V) }\end{array}$ & $\frac{\text { Input Rating: }}{55 \text { gallons }} \leq 75,000$ Btu/hr AND Rated Storage: $>$ \\
\hline & & Oil & $0.68-(0.0019 \times \mathrm{V})$ & No change \\
\hline & & \multirow[t]{2}{*}{ Electric } & $0.96-(0.0003 \times V)$ & $\frac{\text { Input Rating: }}{55 \text { gallons }} \leq 12 \mathrm{~kW}$ Btu/hr AND Rated Storage: $\leq$ \\
\hline & & & $2.057-(0.00113 \times V)$ & $\frac{\text { Input Rating: }}{55 \text { gallons }} \leq 12 \mathrm{~kW}$ Btu/hr AND Rated Storage: $>$ \\
\hline & Tankless & Gas & $0.82-(0.0019 \times V)$ & $\begin{array}{l}\text { Input Rating: }>50,000 \text { Btu/hr to } 200,000 \text { Btu/hr; no } \\
\text { more than } 1 \text { gallon water per } 4,000 \text { Btu/hr of input } \\
\text { AND Rated Storage: } \leq 2 \text { gallons }\end{array}$ \\
\hline
\end{tabular}

** $\mathrm{V}=$ rated storage volume (gallons)

Additionally, since January 2009, the residential market has seen the introduction of an ENERGY STAR program for water heaters. ENERGY STAR standards, developed by DOE and the U.S. Environmental Protection Agency, are voluntary specifications that many customers use as a basis for purchasing equipment that exceeds minimum efficiency levels. ENERGY STAR for water heaters was introduced with the goal of increasing sales of high efficiency water heaters, including gas storage, gas condensing, gas tankless, heat pump, and solar. The current ENERGY STAR efficiency or energy factor (EF) qualifying levels by water heater type are shown in Table 6. 
Table 6. ENERGY STAR Specifications and Qualifying Models ${ }^{27}$

\begin{tabular}{|c|c|c|c|}
\hline Technology & Eligibility Requirements & ENERGY STAR Qualifying Requirements & Comments \\
\hline Gas HE Storage & $\begin{array}{l}\text { - Nominal input of } \leq 75,000 \mathrm{BTU} / \text { hour } \\
\text { - Rated storage volume from } 20 \text { to } 100 \\
\text { gallons. }\end{array}$ & $\begin{array}{l}\text { - Energy Factor } \geq 0.67 \\
\text { - First-Hour Rating }(F H R) \geq 67 \text { gal/hour } \\
\text { - Warranty } \geq 6 \text { years on sealed system } \\
\text { - Safety: ANSI Z21.10.1/CSA } 4.1\end{array}$ & $\begin{array}{l}\text { Many models use power vent } \\
\text { or power direct vent. }\end{array}$ \\
\hline $\begin{array}{l}\text { Gas Condensing } \\
\text { Storage } \\
\text { (Residential) }\end{array}$ & $\begin{array}{l}\text { - Nominal input of } \leq 75,000 \text { BTU/hour } \\
\text { - Rated storage volume from } 20 \text { to } 100 \\
\text { gallons. }\end{array}$ & $\begin{array}{l}\text { - } \mathrm{EF} \geq 0.80 / T E \geq 90 \% \\
\text { - } \geq 67 \mathrm{gal} / \mathrm{hour} \\
\text { - Warranty }>=8 \text { years on sealed system } \\
\text { - ANSI Z21.10.1/CSA } 4.1\end{array}$ & \\
\hline $\begin{array}{l}\text { Gas Tankless } \\
\text { (including } \\
\text { Condensing) }\end{array}$ & $\begin{array}{l}\text { - Nominal input of }>50,000 \text { BTU/hour } \\
\text { and } \leq 200,000 \text { BTU/hour } \\
\text { - Rated storage volume of } 2 \text { gallons or } \\
\text { less }\end{array}$ & $\begin{array}{l}\text { - Energy Factor } \geq 0.82 \\
\text { - First-Hour Rating }(F H R) \geq 67 \text { gal/hour } \\
\text { - Warranty } \geq \\
\text { - } 10 \text { years on heat exchanger and } 5 \text { years on } \\
\text { parts } \\
\text { - Safety: ANSI Z21.10.3/CSA } 4.3\end{array}$ & $\begin{array}{l}\text { Over } 130 \text { models have } \\
\text { achieved Energy Factors } \\
\text { (EFs) of } 0.90 \text { or higher, } \\
\text { typically with condensing } \\
\text { technology. }\end{array}$ \\
\hline $\begin{array}{l}\text { Electric Heat } \\
\text { Pump (integrated } \\
\text { units only) }\end{array}$ & $\begin{array}{l}\text { - Maximum current rating of } 24 \\
\text { amperes } \\
\text { - Voltage } \leq 250 \text { volts } \\
\text { - Transfer of thermal energy from one } \\
\text { temperature to a higher temperature } \\
\text { level for the purpose of heating water. } \\
\text { - Unit must have "integrated" or "drop- } \\
\text { in" configuration }\end{array}$ & $\begin{array}{l}\text { - Energy Factor } \geq 2.0 \\
\text { - First-Hour Rating (FHR) } \geq 50 \text { gal/hour } \\
\text { - Warranty } \geq 6 \text { years on sealed systems } \\
\text { - Safety: ANSI Z21.10.3/CSA } 4.3\end{array}$ & $\begin{array}{l}\text { EFs range from } 2.0 \text { to } 2.5 \text {. } \\
\text { Add-on heat pump units, } \\
\text { which can be coupled with } \\
\text { existing gas or electric } \\
\text { storage water heaters, do not } \\
\text { qualify for ENERGY STAR. }\end{array}$ \\
\hline Solar & Auxiliary tank must be residential-class. & $\begin{array}{l}\text { - Electric EF } \geq 1.8 \text { (solar fraction must be } 0.50 \text { ) } \\
\text { - Gas EF } \geq 1.2 \text { (solar fraction must be } 0.50 \text { ) } \\
\text { - Warranty >= } 10 \text { years on solar collector, } 6 \text { years } \\
\text { on storage tank, } 2 \text { years on controls and } 1 \text { year } \\
\text { for piping and parts } \\
\text { - Safety: OG-300 Certification from the SRCC }\end{array}$ & $\begin{array}{l}\text { Solar fraction }=1-\text { (Energy } \\
\text { Factor/Solar Energy Factor), } \\
\text { assuming an EF of } 0.90 \text { for } \\
\text { electric back-up and an EF of } \\
0.60 \text { for gas back-up. }\end{array}$ \\
\hline
\end{tabular}

HE - high efficiency

EF - Energy Factor

TE - Thermal efficiency

\section{Market and Technical Challenges and Barriers}

Despite the increase in sales of ENERGY STAR-qualifying water heaters in recent years, the majority of water heaters sold in the United States still just meet the minimum efficiency standard. In particular, the highest efficiency models -including heat pump water heaters and solar water heaters - represent a very small portion of shipments. The key barriers to implementing high-efficiency equipment and systems for hot water production and distribution include first cost, price premiums that are difficult to up-sell due to a lack of non-energy benefits, emergency replacements that require immediate product availability and prevent discussion of higher efficiency alternatives, and split incentives (in new construction).

Like most major appliances, water heaters represent a large initial expense. Although high-efficiency options can provide positive life-cycle returns through lower operating costs, the additional cost above

${ }^{27}$ http://www.energystar.gov/index.cfm?c=water heat.pr crit water heaters 


\section{NAVIGANT}

an already significant base expense represents a financial commitment that many customers are unwilling or unable to make. First cost is a barrier to many high-efficiency appliances but unlike white goods or even HVAC, there are few, if any, premium features of a water heater (e.g., comfort, aesthetics, image, and enhanced functionality) that can be leveraged to up-sell high-efficiency products. The Coalition For ENERGY STAR Water Heaters ${ }^{28}$, a national awareness and education campaign managed and conducted by Consortium for Energy Efficiency and sponsored by manufacturers, industry associations and energy efficiency program administrators, is working to address this issue.

Furthermore, most residential water heater replacements occur as emergency sales where immediate availability is essential to maintain comfort and function (whether in a home or a restaurant). Most emergency replacements are filled with the equipment on the plumber's truck so upgrading to more energy-efficient units is not feasible due to availability, installation requirements, or both. Utility-level financing options, such as equipment leasing, could be an option to reduce the first cost of efficient equipment. In new construction, the building or installation contractor chooses the equipment more often than the homeowner, a situation known as a split incentive; in commercial scenarios, the building owner may make the decision but first cost often takes priority. Similarly, more efficient hot water distribution systems can be designed and installed in new buildings but they are almost invisible to developers and are invisible (barring a catastrophic failure leading to flooding and/or loss of hot water) to consumers.

The equipment replacement market is a critical element for reaching economies of scale in the water heating market. Therefore, research is needed to identify and characterize the hot water loads and use patterns for the large base of existing buildings and to develop advanced and more efficient technology solutions to cost effectively meet those loads. The American Society of Heating, Refrigerating, and AirConditioning Engineers' research project 1544-TRP, Establishing Benchmark Levels and Patterns of Commercial Building Hot Water Use, focusing on hotels with both food service facilities and more than 100 rooms, is an example of the former.

The key market and technical barriers to high-efficiency water heating are summarized in Table 7.

Table 7. Water Heating - Challenges and Barriers

Market Barrier
Title

Description

The BTP strategy requires development of much more affordable systems. Many high- efficiency products and systems are already available in the marketplace, but are far too expensive for widespread adoption, particularly for existing buildings. Any new technology or system developed must be cost competitive with today's technologies, offering an acceptable payback period. Recent focus group studies have suggested that consumers have an implicit one-year payback on investment in energy-saving technologies; however, marketing strategies that identify products as "green" or otherwise beneficial to the environment can help offset this implicit barrier (e.g., the relatively large sales of hybrid electric vehicles). ${ }^{29}$

\footnotetext{
${ }^{28}$ http://www.eswaterheaters.org/

${ }^{29}$ Bill Goetzler, “Air Conditioning Market \& Technology Trends”, presented at ARPA-E BEETIT, December 7, 2010.
} 


\begin{tabular}{ccc}
\hline B & $\begin{array}{l}\text { New products need to be easily installed and maintained without necessitating } \\
\text { substantial additional training for installers or requiring additional trades' personnel. } \\
\text { Reliability must be proven to at least match that of current HW systems. Current } \\
\text { advanced electric WHs (HPWHs) are generally taller and require more space for } \\
\text { proper performance - both these impose some installation constraints and can } \\
\text { impede builder/developer and consumer acceptance. HPWHs (gas or electric) will } \\
\text { add to space heating loads but reduce space cooling loads if installed in } \\
\text { conditioned space and will impact consumer comfort/acceptance positively or } \\
\text { negatively depending on location. Venting requirements, such as those required in } \\
\text { the Northern Tier specification, will greatly reduce this as an issue for the heating } \\
\text { acceptance }\end{array}$ \\
\hline Season.
\end{tabular}

The basic design concept for hot water systems for residential and commercial buildings has changed very little in the past decades-evidenced even in the form of the products, which look much the same as they did 20 years ago. Because incremental improvements and minimum efficiency standards such as the National Appliance Energy Conservation Act, the Energy Policy Act and ASHRAE 90.1, have captured much of the "low-hanging fruit" efficiency gains, achieving BTP's aggressive goals requires innovative design approaches.

\section{Strategies for Overcoming Market and Technical Challenges and Barriers}

Table 8 describes the strategies for overcoming barriers and challenges for water heating. 
Table 8. Water Heating Strategies for Overcoming Market and Technical Barriers and Challenges

\begin{tabular}{|c|c|c|}
\hline Barrier & Title & Strategy \\
\hline A & Affordability & $\begin{array}{l}\text { Designs and systems must be able to be mass-produced, and the concepts } \\
\text { may not incorporate other features that raise costs without any energy } \\
\text { benefit. }\end{array}$ \\
\hline B & Market acceptance & $\begin{array}{l}\text { Advanced concept designs and systems should be as simple as possible } \\
\text { with use of conventional components, and feature relatively easy installation } \\
\text { and low maintenance. Market studies are needed to help address questions } \\
\text { related to market acceptance. }\end{array}$ \\
\hline C & Energy savings not a driver & $\begin{array}{l}\text { ENERGY STAR labeling will help increase consumers' awareness of the } \\
\text { potential energy use savings of advanced equipment. Similar means are } \\
\text { needed to increase awareness of improved distribution system and hot } \\
\text { water load/use reduction technologies. Marketing/advertising strategies are } \\
\text { needed to tout advanced WH equipment/systems' benefits like enhanced } \\
\text { stewardship of natural resources, home resale value (e.g., hybrid vehicles } \\
\text { have nowhere near a one-year payback based on fuel savings yet have } \\
\text { managed to capture the imagination of the public and an increasing share of } \\
\text { vehicle sales). }\end{array}$ \\
\hline
\end{tabular}

D Sustained performance

Designs will include integrated FDD systems or should tolerate typical faults such as modest loss of refrigerant charge without significant performance deterioration.

Develop new concepts like smart controls and approaches such as waste heat recovery (possibly via integration with drain water, other appliances, or the HVAC systems) that are not easily captured by the current EF metric but

E System efficiency that can reduce energy consumption dramatically. A new test standard/metric may be needed to fairly capture the benefits of such novel developments. Develop innovative, low thermal loss hot water distribution approaches that can potentially be used in both new and existing buildings. Develop innovative ways to reduce hot water usage, and loads. 


\section{Research and Development Roadmap}

To overcome the barriers outlined in the preceding section and achieve the strategic goals of the DOE BTP program to reduce building energy consumption and related carbon emissions, an integrated and systematic R\&D program focused on advanced technologies to meet building hot water service needs is planned. The program must focus not only on improving the efficiency of water heating equipment (e.g., gas, electric, solar, and combined) but also on improving hot water distribution systems, reducing hot water usage/loads, and recovering waste heat. There will be no one "best" cost optimal solution for all building types throughout the U.S. Furthermore, optimal solutions may be different for existing versus new construction and for different climate zones. Finally, issues related to policy and markets will also be addressed.

\section{Near-Term Technology Options -Years 2012-2019 Time Horizon}

This section presents research and development ideas for calendar years 2012 through 2019. The following sections provide additional details on the R\&D roadmaps for each R\&D Target.

\section{Roadmap for RED Target 1: Equipment}




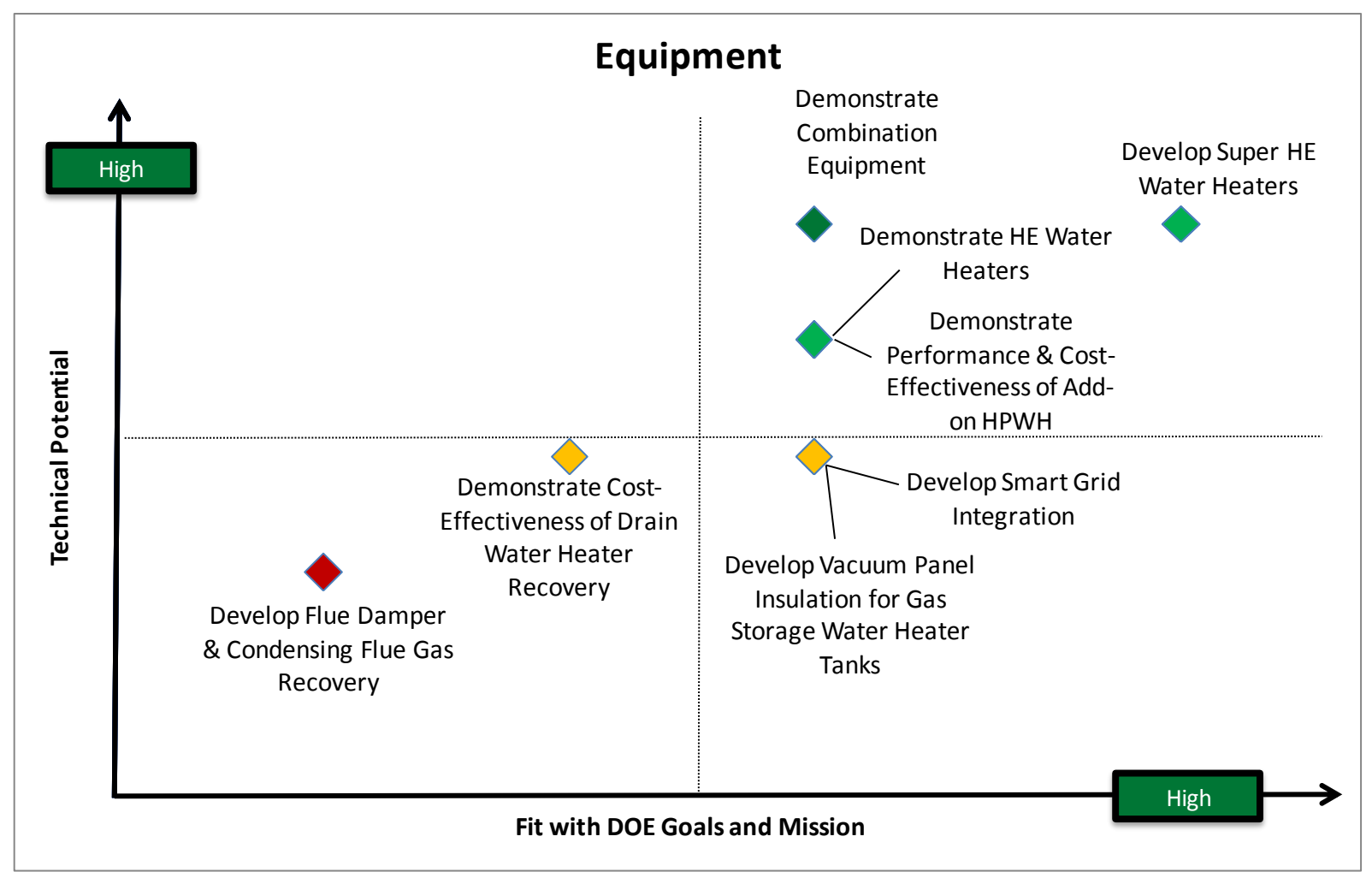

Figure 5. Equipment - Prioritization of Options

Potential equipment R\&D projects were assessed according to their fit with the BTP goals and mission as well as their technical energy savings potential. BTP fit was analyzed by considering whether DOE involvement would be important to the success of the endeavor, or whether market forces would likely address the R\&D need without BTP involvement. Furthermore, incremental engineering improvements are not appropriate activities for DOE R\&D, while moderately high risk R\&D is more appropriate. Technical energy savings potential was assessed using the predicted savings of the equipment multiplied by the potential market size. The results of this assessment, and the associated priorities of the projects, are provided in Figure 5.

Near-term hot water R\&D efforts should focus on activities aimed at overcoming technical and market barriers to more efficient equipment and distribution systems. Although higher efficiency water heating equipment (e.g., HPWHs, tankless water heaters, and solar water heaters) and lower-loss distribution approaches exist, their market uptake to date is limited. Projects involving field tests and demonstrations, cost reduction efforts, support for new minimum efficiency standards development, and development of technologies are likely needed to overcome these barriers. 


\section{R\&D TARGET 1: EQUIPMENT}

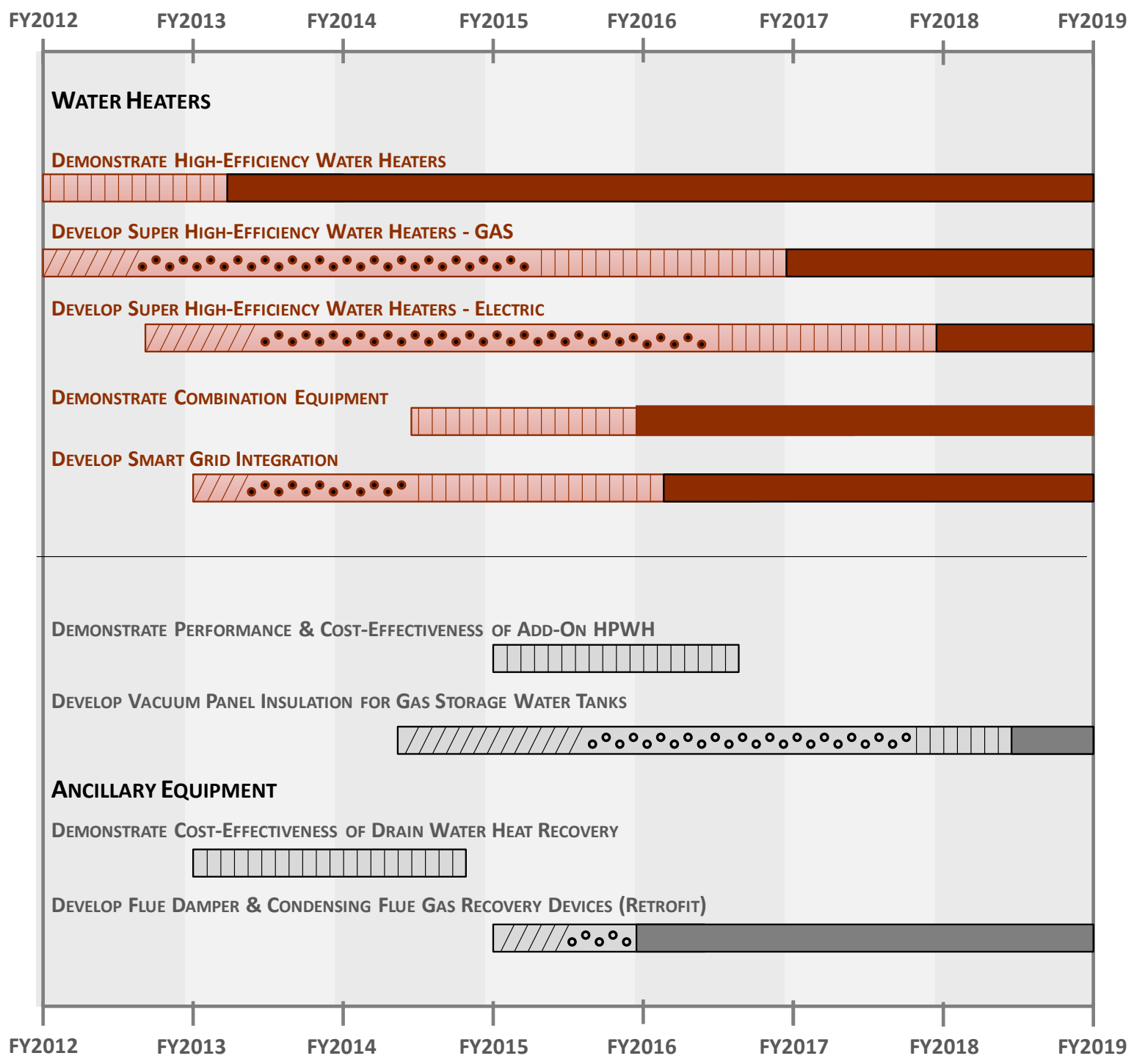

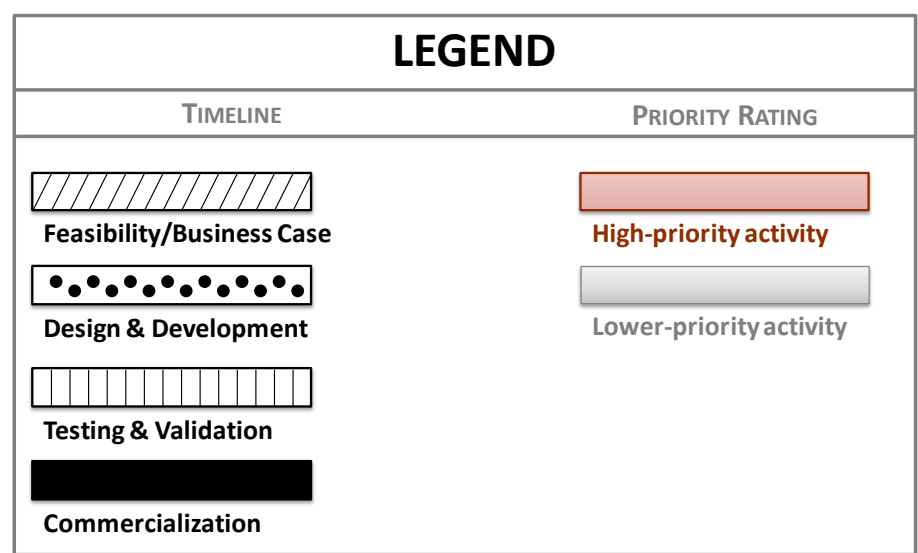

Figure 6. Timelines \& Priorities for R\&D Target 1: Equipment 


\section{NAVIGANT}

\section{Water Heaters}

Key R\&D initiatives related to water heating equipment are summarized in Figure 6 and described in the following section.

- Demonstrate high-efficiency water heaters - While many high-efficiency models are cost effective over their lifetimes, the high discount rates demanded by consumers, particularly in the residential market, often render devices with lower life-cycle costs less attractive than those with lower first cost. The focus of this effort would be to conduct relatively large-scale field tests of existing highefficiency water heater options to provide consumers, manufacturers, utilities, other government agencies, and other interested parties with increased assurance of the energy and cost savings potential, reliability and robustness of the new technologies. The outcome of this project would be to generate data that would enable others to implement the technology and demonstrate the value and reliability of the technology to customers.

- Develop super-high-efficiency water heaters (next generation) - By leveraging heat pump technology or other new design approaches, advanced water heaters with EFs that approach the 2020 DOE BTP targets of 4.4 (for electric water heaters) and 1.5 (for gas water heaters) could be developed. The outcome of this project would be to commercialize gas heat pump water heaters and super-high efficiency electric heat pump water heaters. With millions of storage water heaters sold every year, the potential market for this equipment is extensive, and the savings potential is very high. The market includes residential and commercial water heaters.

- Gas-fired heat pump technology is technically feasible but has not been demonstrated. Based on existing research and development work, working models with EFs greater than 1.0 may be realized as early as 2013. A suggested Work Breakdown Structure (WBS) for this R\&D option is provided in Figure 7.

- Current electric heat pump water heaters (HPWH) use hydrofluorocarbon refrigerants as their working fluids. An initial scoping study performed by ORNL demonstrated feasibility of achieving EF in the range of 3.0 using R-134a, and possibly using R-1234yf with best available component technologies. ${ }^{30}$ Carbon dioxide $\left(\mathrm{CO}_{2}\right)$ is also suitable for HPWHs, allows for very high efficiency, and has less significant direct global warming impacts than hydrofluorocarbon refrigerants. High efficiency $\mathrm{CO}_{2} \mathrm{HPWHs}$ have been developed and commercialized in Japan, however, their viability in the U.S. market would depend on dramatic cost reduction and redesign for the U.S. market, as well as addressing safety and service concerns. The savings potential associated with advanced, super high efficiency electric HPWHs is very high: in Japan, the coefficients of performance are in the range of 4.0. This is roughly one and half to two times the performance of existing HPWHs, which themselves represent a major increase in efficiency over conventional electric water heaters. By 2015, a 50-gallon heat pump water heater using $\mathrm{CO}_{2}$ or other low GWP working fluids may be available to consumers for around \$2,000 per unit; this cost is higher than the heat pump units currently on the market, however, the increased efficiency would improve the payback. A suggested WBS for this R\&D option is provided in Figure 8.

\footnotetext{
${ }^{30}$ Baxter, Van et. al., Analysis of Highly Efficient Electric Residential Heat Pump Water heaters for Cold Climates, ORNL/TM-2011/278, Oak Ridge National Laboratory, September 2011.
} 


\section{NAVIGANT}

- High-efficiency and lower cost solar water heaters are also expected to be important additions to the next generation solutions, and will be discussed in detail in a separate Solar Water Heating R\&D Roadmap. 
Work Breakdown Structure: Gas Powered Heat Pump Water Heater

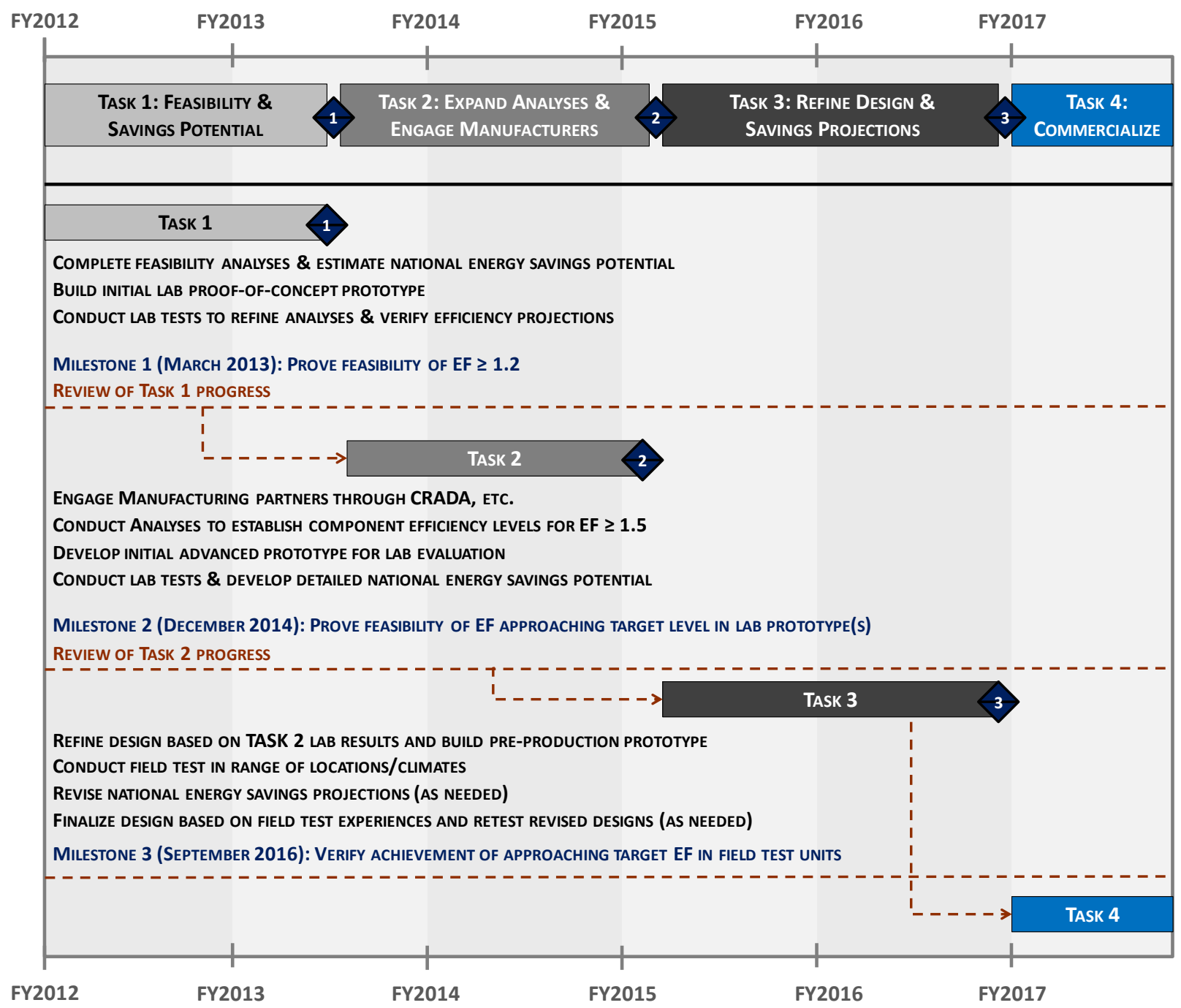

Figure 7. Work Breakdown Structure for Gas Powered HPWH 
Work Breakdown Structure: Advanced Electric Heat Pump Water Heater

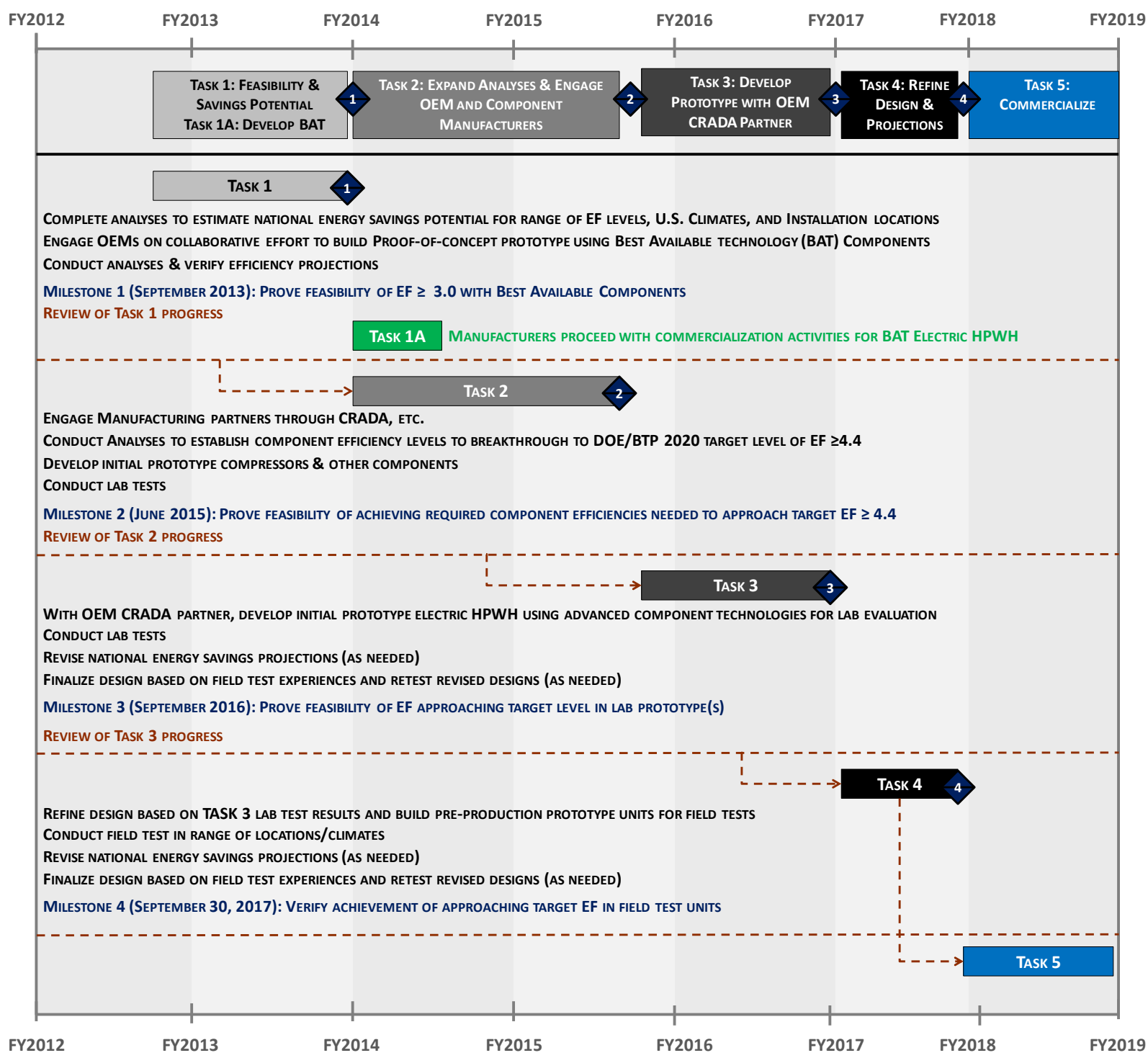

Figure 8. Work Breakdown Structure for Advanced Electric HPWH

- Demonstrate combination equipment - Combining water heating with other building functions can help leverage the incremental cost of efficient technologies across several building systems, make use of "free" waste heat from other systems, or otherwise enhance the cost-effectiveness of highefficiency water heating. Ensuring high reliability for combination equipment is critical due to the additional complexity of the system. A few examples include:

- Combining with other technologies such as micro-CHP, solar, and geothermal

- Combined space and water heating where water heating is the primary use

- Co-location of heat pump water heaters with distribution transformers

- Small exhaust air-source heat pump water heaters for lavatories 


\section{NAVIGANT}

The goal of this project would be to demonstrate savings, reliability, and overall performance of various types of combination equipment. The potential savings associated with combination equipment is very good, however, the market for these technologies are limited by their specialized nature of their potential applications.

- Develop Smart Grid integration - Water heaters could become part of a utility's load curtailment strategy if equipped with the appropriate technology. The technology would need to be able to sync with the Smart Grid as well as provide feedback to the user regarding activity- or appliance-specific energy and cost information. The user interface is a critical aspect of developing effective Smart Grid integration, and water heating technologies for Smart Grid should leverage lessons learned from other enabled appliances. Smart Grid integration would provide benefits in terms of peak demand reduction, carbon emissions, and potentially in cost savings, however, the direct energy savings would be limited.

- Develop and demonstrate low-cost solar systems - Solar water heating works in a wide variety of climates. However, due to its extremely high cost $(\$ 5,000-\$ 10,000$ installed for typical homes), solar water heating is typically cost effective only in areas with a combination of high energy prices and good solar incidence, such as Hawaii. Radically new designs with much lower costs $(<\$ 2000)$ are required to make solar water heating viable more broadly throughout the U.S. Because solar water heating is a distinct technology with particular challenges and opportunities, a separate SWH roadmap is currently being developed by NREL, and the technology is not shown in Figure 6.

- Demonstrate performance and cost-effectiveness of add-on heat pump water heaters - To date, testing for HPWHs has focused on "drop-in" models, which include the hot water storage tank and heat pump unit, over add-on HPWHs, which include only the heat pump components (compressor, evaporator, and air circulating fan). A PG\&E lab test conducted in 2010 demonstrated the performance of the AirTap, one of the most prominent add-on units available in the U.S., was in line with the manufacturer rating of EF 2.11 and first-hour rating of 42.5 (results showed EF 2.14 and first-hour rating of 45). ${ }^{31}$ Field-testing of a range of add-on units (approximately 50-100 in total) in different climates would establish performance information that does not currently exist. If possible, a demonstration project should also consider the potential impact of water quality and corrosion issues on long-term reliability. Add-on heat pump water heaters could effectively serve as a retrofit option for the existing stock of storage water heaters.

- Develop vacuum panel insulation for storage tanks - The efficiency of storage water heaters could be enhanced with better insulation to reduce heat loss through the tanks. Because the overall diameter of the water heaters is constrained by the need to fit into confined spaces while maintaining internal tank volume, tank insulation thickness cannot be increased. Vacuum panel insulation, whose insulating properties are superior to polyurethane foam, would greatly reduce heat transfer in storage water heaters, however, R\&D would be required to develop durable and cost-effective options for this purpose. The savings benefit from vacuum panel insulation would be limited.

${ }^{31}$ PG\&E Applied Technology Services, Laboratory Evaluation and Field Testing of Residential Heat Pump Water Heaters, ATS Report\# 491-10.04, 2010. Available: http://www.etcc-ca.com/savings-for-home/2985-laboratoryevaluation-and-field-testing-of-residential-heat-pump-water-heaters 


\section{NAVIGANT}

Ancillary Equipment

- Demonstrate cost-effectiveness and energy-saving potential of drain water heat recovery - Drain water heat recovery systems capture heat from water going down the drain after the heated water is used for another purpose such as showering, clothes washing, or dishwashing. Residential, commercial, and institutional installations are feasible. Although gaining popularity in Canada, drain water heat recovery has not been adopted in the United States. The purpose of field-testing in a range of climate zones across the country would be to demonstrate the potential and costeffectiveness of the technology.

- Developing aftermarket efficiency-improvement devices (e.g., flue damper and condensing flue gas recovery) - Although aftermarket devices could be developed to improve the baseline efficiency of water heating equipment, the potential savings from these devices is small. More importantly, however, the use of an aftermarket device may void the manufacturer warranty, creating an area of liability for water heating products that is undesirable. Aftermarket devices could be installed on older equipment (with expired warranty) without liability concerns but the potential market is significantly narrower than the full retrofit market. Manufacturers could also elect to develop aftermarket devices for their own products, or with approval from the original equipment manufacturer. This is not an R\&D target that fits well with DOE's mission.

\section{Roadmap for RED Target 2: System Design, Operation, and Maintenance}

R\&D activities associated with water heating system design (with particular focus on the distribution part of the total system), operation, and maintenance are summarized in Figure 10 and described in greater detail below.

Potential systems (design, operation \& maintenance) R\&D projects were assessed according to their fit with the BTP goals and mission and potential to address a critical gap in knowledge that would lead to savings and/or market transformation. BTP fit was analyzed by considering whether BTP involvement would be important to the success of the endeavor, or whether market forces would likely address the R\&D need without BTP involvement. Potential to address a critical knowledge gap was assessed using current understanding of the knowledge gaps around key research areas. The results of this assessment, and the associated priorities of the projects, are provided in Figure 9. 


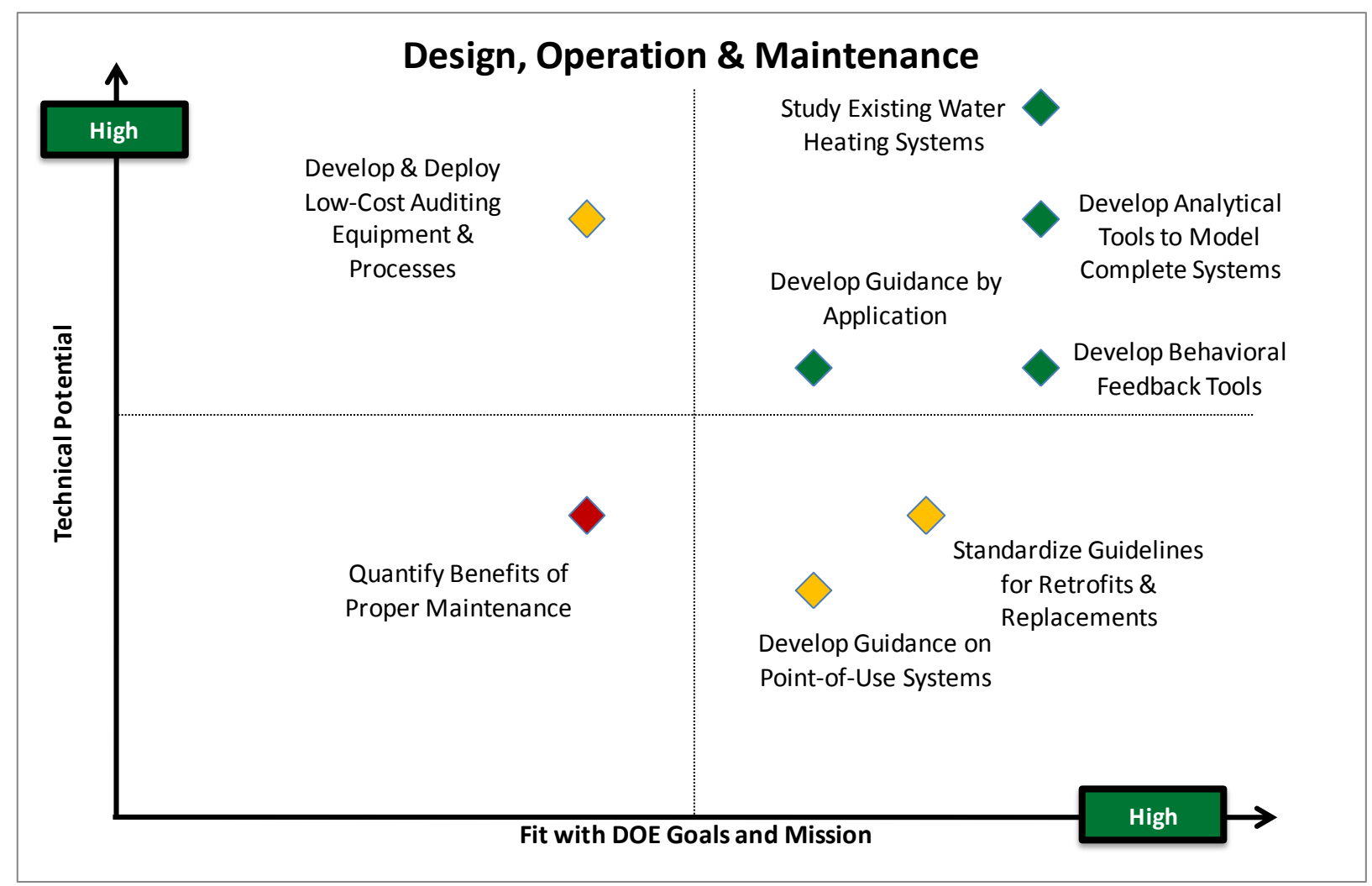

Figure 9. Design, Operation \& Maintenance - Prioritization of Options 


\section{R\&D TaRget 2: Design, Operation \& Maintenance}

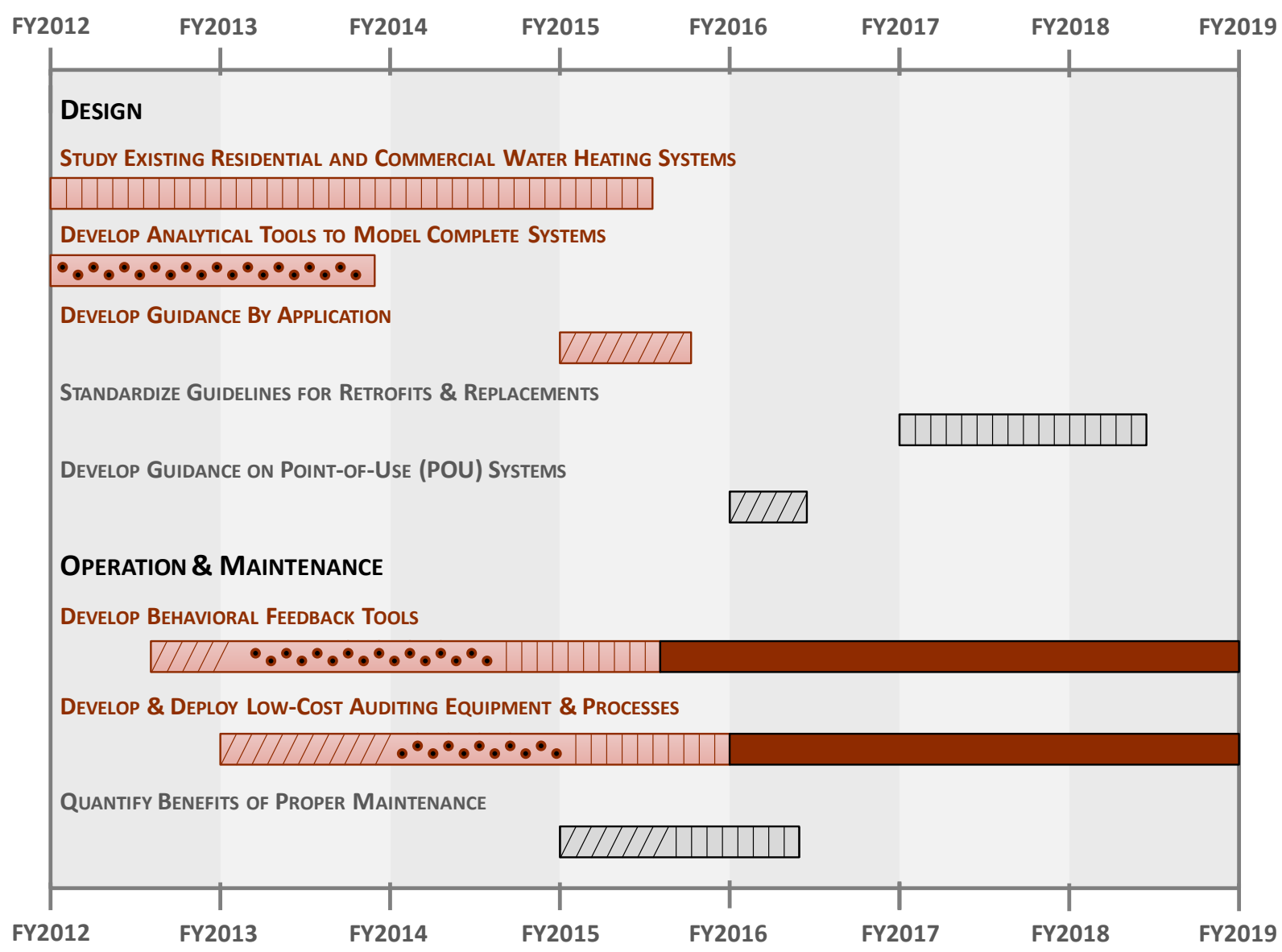

\begin{tabular}{|c|c|}
\hline \multicolumn{2}{|c|}{ LEGEND } \\
\hline TIMELINE & PRIORITY RATING \\
\hline \multicolumn{2}{|l|}{ DIIIIIIIIIIID } \\
\hline Analysis & High-priority activity \\
\hline \multicolumn{2}{|l|}{ 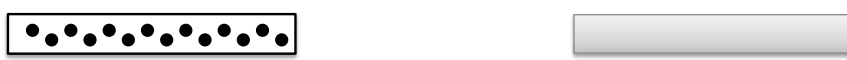 } \\
\hline Development & Lower-priority activity \\
\hline 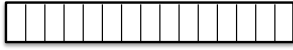 & \\
\hline \multicolumn{2}{|l|}{ Demonstration } \\
\hline Deployment/Col & \\
\hline
\end{tabular}

Figure 10. Timelines \& Priorities for R\&D Target 2: Design, Operation \& Maintenance

\section{Design}

- Study existing residential and commercial water heating distribution systems to understand the effect of loads and use patterns and quantify the benefits of good design - Specific technology 


\section{NAVIGANT}

solutions could be developed and building design guides could be enhanced with better insight into how distribution system layout and use patterns affect resource consumption. This analysis would provide important information about water systems and behavior that could enable major changes in system design and operation. A suggested WBS for this R\&D option is provided in Figure 11.

- Collect field data on existing water heating systems: Conduct comprehensive field analysis of various distribution systems (single family, multifamily, some nonresidential). The field analysis should examine many different existing systems to understand how they function, where opportunities exist, and where/how efficiency has been achieved.

- Analyze loads and use patterns: Water heating loads and use patterns influence equipment energy use; however, their impact (amplifying and/or mitigating) in different building types and plumbing layouts is poorly understood. Research on system layout should include analysis of how loads and use patterns affect energy use in different systems. For example, how much of an impact does behavior have on the energy use of a well-designed system versus a poorly designed system?

- Quantify benefits of good design to develop design guides for highly efficient distribution: Savings associated with good design practice - which, for example, aims to limit the distance between the water heater and end-use fixtures, and calls for insulation on pipes - have not been demonstrated with robust field data. Collecting detailed data on performance based on distribution system layout could provide proof of concept, and ultimately lead to better design guides for developers, contractors, and plumbers. Typically, water heating distribution system design is not a priority during building construction but persuasive evidence of savings may change industry's approach or become part of building code. 


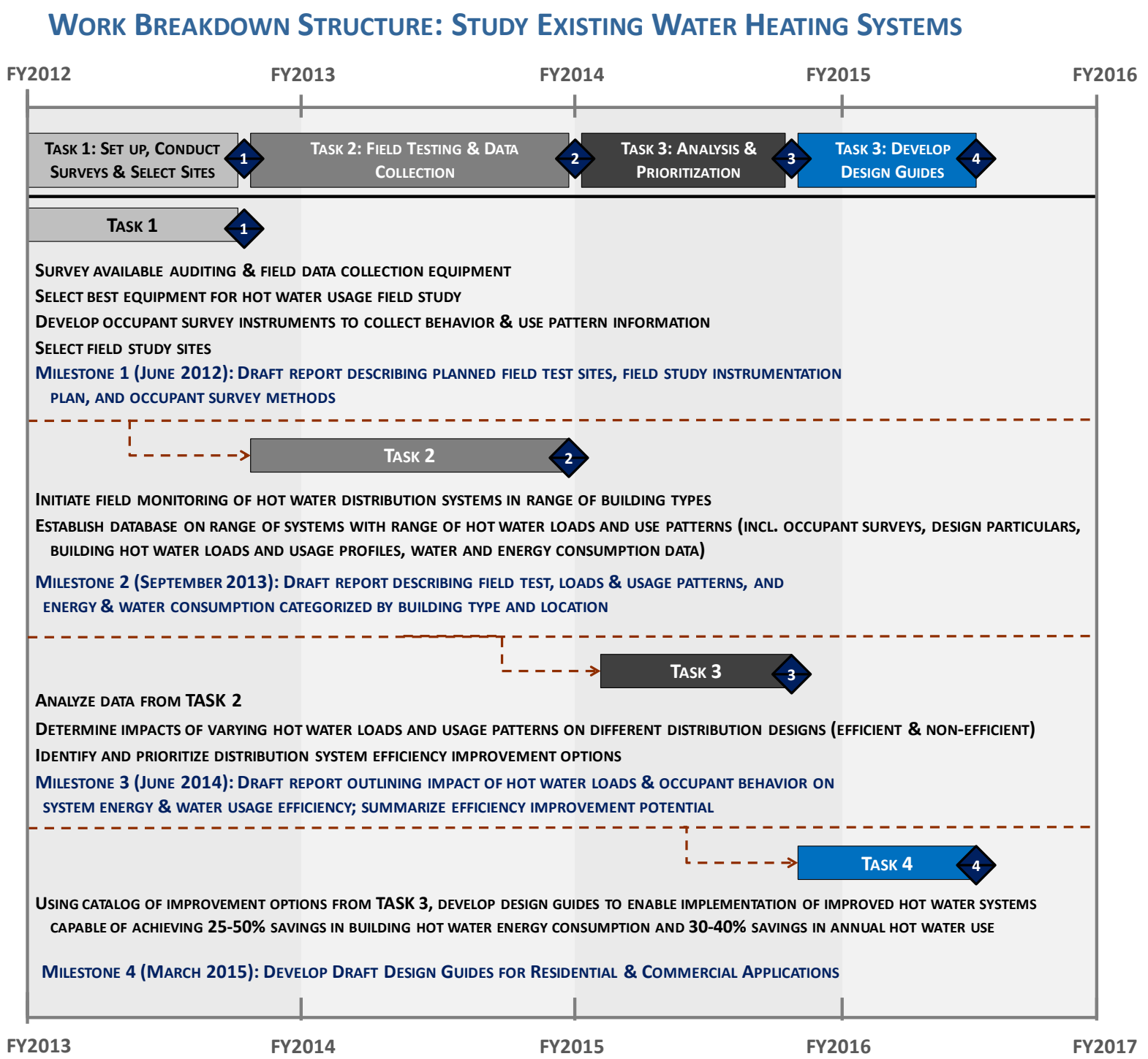

Figure 11. Work Breakdown Structure for Study of Existing Water Heating Systems

- Develop analytical tools to model complete systems - User-friendly software tools to model complex water heating systems, including both water heaters and distribution systems and interactions between the two, would enable building designers and contractors to evaluate alternative system designs to assess energy consumption as well as cost-effectiveness.

- Standardize guidelines for retrofits and replacements - Tools and training for the residential market are needed to ensure optimum design in retrofit and replacement scenarios. For example, a home that has upgraded its appliances to high-efficiency models may require a smaller water heater than what was previously installed, or a new HPWH may require a different installation location if the original location does not offer sufficient ventilation. Providing contractors and homeowners with tools and training will help ensure that retrofits and replacements optimize system efficiency in a particular home or building. 
- Develop guidance on point-of-use (POU) systems - POU water heaters can improve system performance and end-user satisfaction. POU water heaters can be applied where an end-use is located far from the central unit (e.g., a bathroom at the opposite end of the house) or where an infrequent use lowers system efficiency by requiring a very large water heater to turn on for a small, short draw (e.g., hot water for a bathroom sink in an industrial facility). Robust guidance on the efficiency and cost-effectiveness of POU water heaters is needed to assist customers and installers in making equipment decisions for their systems. POU water heaters are limited in their applications but may improve overall system efficiency and performance.

- Develop guidance by application - Best practice design guides by application (single family, multifamily, and nonresidential), including climate, would be useful across the water heating industry. Tools to select the most cost-effective water heater for a specific application based on actual average water use, load-type, climate factors, and other key parameters, would be well received. In particular, there is a desire for interactive design guides that could be used by professionals to further their mastery of energy-efficient design.

HPWHs provide an example of need for climate-specific guidance:

Initial field testing of HPWHs has shown that temperature and humidity have a significant effect on performance. In recognition of this, over 20 utilities are collaborating on a Northern Tier Specification aimed at improving HPWH performance in Northern climates, defined as having an average annual temperature below $60^{\circ} \mathrm{F}$ and over 4,000 heating degree days. ${ }^{32}$ For warm and humid climates, where HPWHs are found to be most effective, design guidance would help installation contractors and homeowners maximize the benefits of the cold, dehumidified air ejected by the HPWH.

Operation and Maintenance

- Develop behavioral feedback tools - Behavioral mechanisms are increasingly recognized for their potential to improve energy efficiency by providing consumers with information about their choices and habits. Water heaters are not yet equipped to deliver sophisticated behavioral feedback. A first step would be data collection on behavioral patterns by household size, building vintage, and equipment type/age, and assessments of the trade-offs consumers make between efficiency and comfort, to inform the type and form of information. Eventually, behavioral feedback tools could be integrated with web-based applications and the Smart Grid.

- Develop and deploy low-cost auditing equipment and standardized auditing processes - Auditing provides end-users and facility operators with valuable insight into areas of inefficiency and/or failures in their water heating system. However, auditing services can be involved, invasive, and/or costly. Low-cost, scalable monitoring devices and standardized methods are needed to meter hot water use in homes and facilities, and provide homeowners, operators, utilities, and even manufacturers with consistent information on how to improve the operation of their systems. A suggested WBS for this R\&D option is provided in Figure 12.

\footnotetext{
${ }^{32}$ Northern Tier Specification, http://neea.org/ourwork/documents/HPWHNorthernTierSpecFinal.pdf
} 
Work Breakdown Structure: Develop \& Deploy low-Cost Auditing Tools

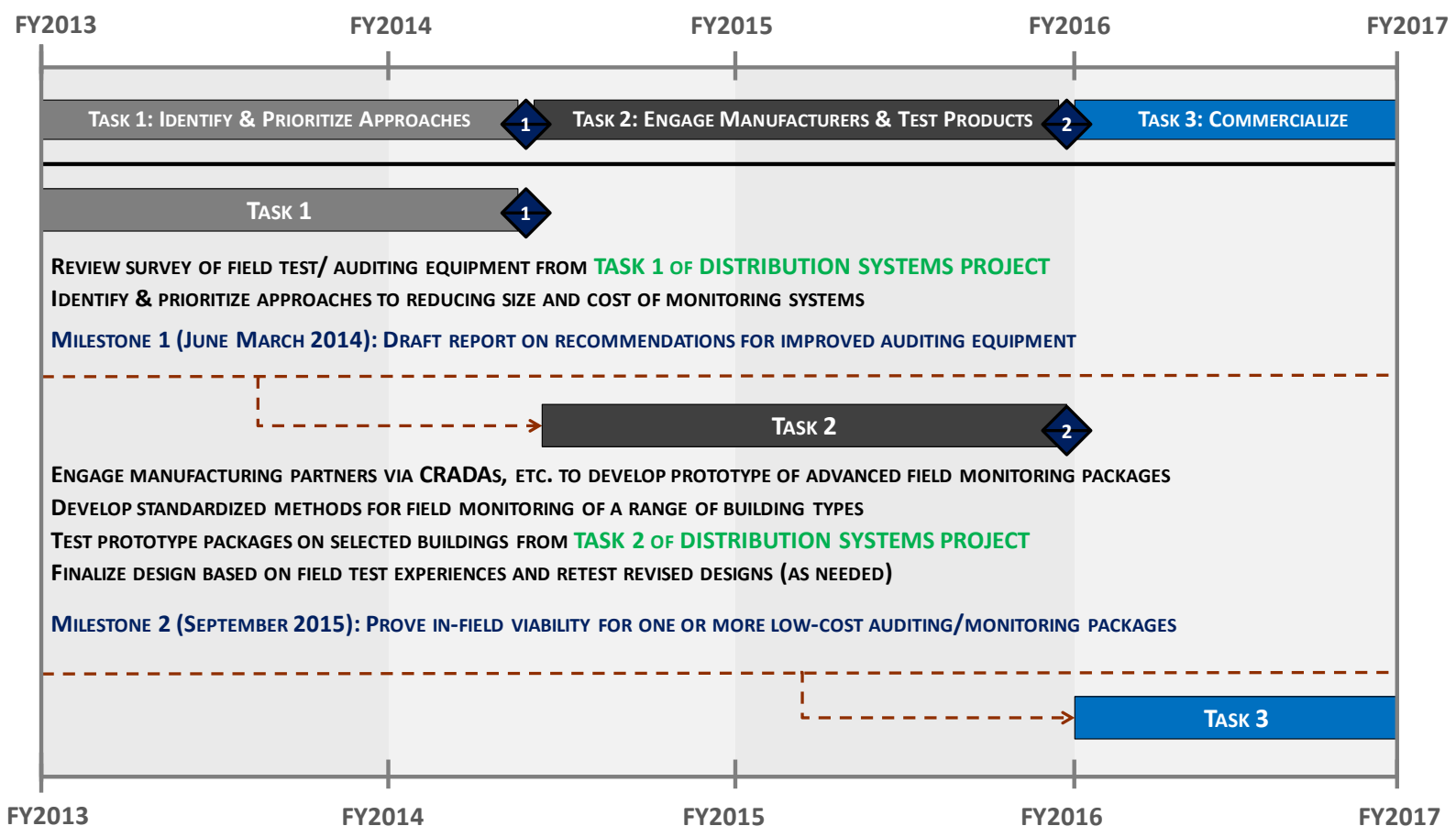

Figure 12. Work Breakdown Structure for Development of Low-Cost Auditing Tools

- Quantify benefits of proper maintenance - Proper maintenance of mechanical systems in buildings, such as HVAC equipment, is an important step to ensure optimum performance throughout the system lifetime. The impacts of proper maintenance (or conversely, performance degradation attributable to lack of proper maintenance) on maintaining performance of hot water systems has not yet been demonstrated through academic research. Thus the benefits, while well recognized by experts and operators, are anecdotal. If the importance of regular maintenance were demonstrated in a rigorous manner-showing the savings in utility costs and emergency repairs, as well as extended lifetime-facility managers and building owners may be more likely to invest in proper upkeep of equipment. 


\section{Roadmap for RED Target 3: Policy and Markets}

Ongoing support of workshops, forums, conferences, and other opportunities to convene a range of actors on a subject is a valuable service that DOE BT provides industry. DOE's work with industry on codes and standards, for proven equipment, and market transformation, for emerging technologies, help to push the market towards higher levels of efficiency.

Potential markets and policy projects were assessed according to their fit with the BTP goals and mission and potential to address a critical gap in knowledge that would lead to savings and/or market transformation. BTP fit was analyzed by considering whether BTP involvement would be important to the success of the endeavor, or whether market forceswould address the R\&D need without BTP involvement. Potential to address a critical knowledge gap was assessed using current understanding of knowledge gaps around key research areas. The results of this assessment, and the associated priorities of the projects, are provided in Figure 13.

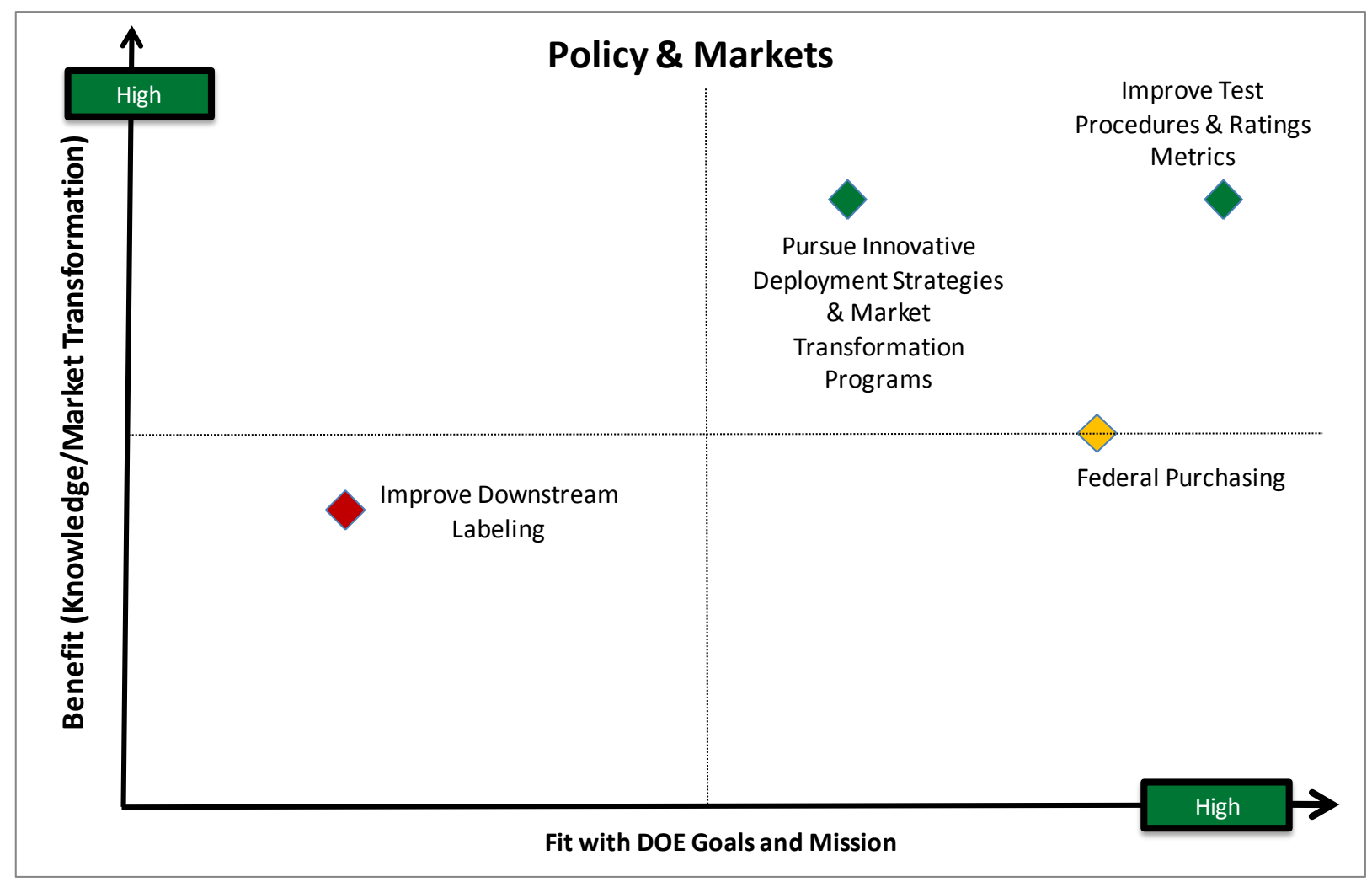

Figure 13. Policy \& Markets - Prioritization

Activities associated with policy and markets are illustrated in Figure 14 and described below. 
R\&D TARget 3: Policy \& Markets

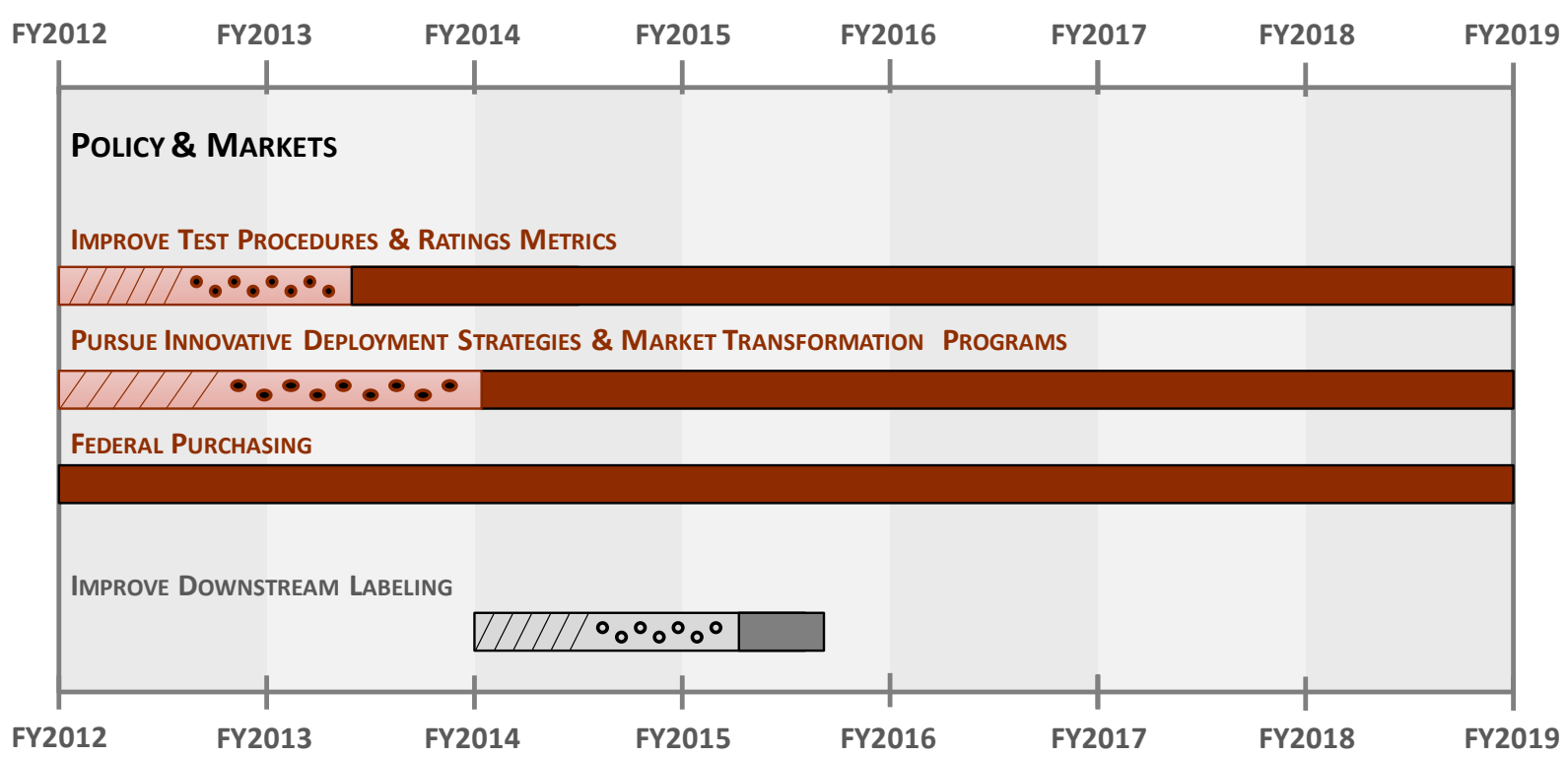

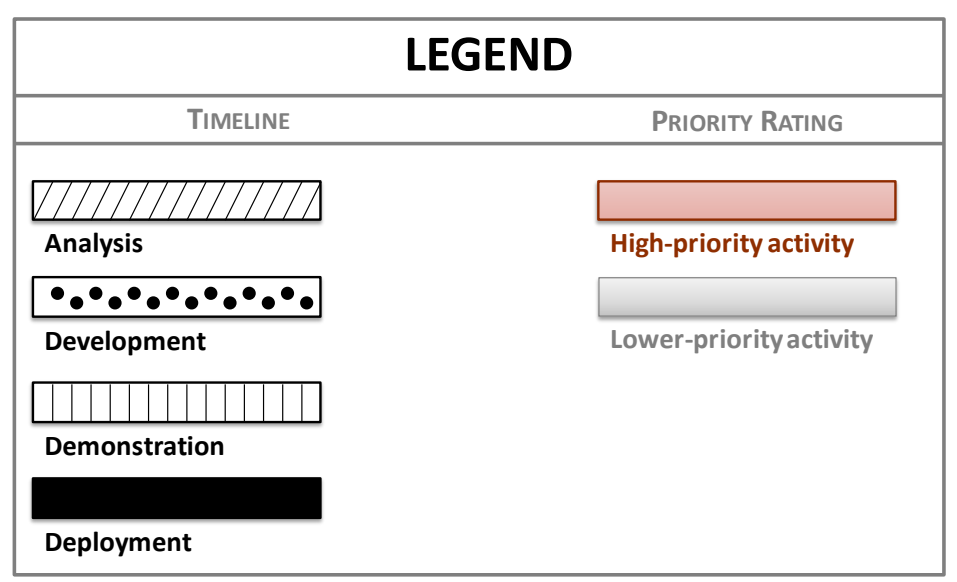

Figure 14. Timelines \& Priorities for R\&D Target 3: Policy \& Markets

- Improve test procedures and rating metrics - Existing test procedures and rating metrics for water heaters are a "one size fits all" approach to evaluating performance. The biggest need is a technology neutral test procedure that, in terms of field usage, fairly rates technologies relative to one another. DOE and AHRI are currently engaged in developing a technology neutral test procedure for water heaters. Another limitation of current test procedures is that they do not provide insight on performance under circumstances that vary significantly from the test conditions. For example, Energy Factor does not account for differences (local, state, or regional) in climate or in daily water consumption by different end uses or household sizes, two factors that affect product selection and/or how well a unit performs in real-world applications. Although local-level standards are implausible, regional standards for climate-sensitive equipment like heat pump water heaters would provide customers with better information regarding performance. Also, current rating methods for 


\section{NAVIGANT}

water heaters do not assess water usage and water waste, which can be a very important feature for some customers.

- Other standards - There are no standards for water heating systems or for point-of-use and combination equipment. Standards are needed to facilitate market adoption.

- Pursue deployment strategies and market transformation programs that maximize consumer product awareness and adoption - The federal government's existing efforts on market transformation include the ENERGY STAR and WaterSense programs. For new-to-market, highefficiency equipment, more aggressive market transformation efforts are needed. Innovative deployment strategies, such as working with manufacturers to offer midstream incentives to big-box retailers and distributors for high-efficiency water heaters, could be coordinated with market transformation programs offered by utilities and organizations such as the Consortium for Energy Efficiency (CEE). CEE's Coalition for Energy Star Water Heaters ${ }^{33}$ is a national awareness and education campaign that could be leveraged for this purpose.

- Federal purchasing - The Federal Energy Management Program (FEMP) establishes purchasing guidelines on energy-consuming devices for federal agencies. Because FEMP guidelines are used by numerous federal agencies and drive a large volume of purchases, they can have a substantial impact on market uptake of emerging technologies by demonstrating energy savings benefits and reliable operation. Therefore, coordination of new product introductions with FEMP can help validate new technologies and facilitate broad market acceptance, while also driving down costs as a result of higher manufacturing volumes.

- Improve financing options for high efficiency water heaters - First cost is a major barrier to the widespread adoption of higher efficiency water heaters. Apart from reducing the costs of these technologies, which typically occurs with economies of scale, creative financing solutions provided by utilities and local or state governments can make the difference between affordable and out-ofbudget purchases. An example of this is on-bill financing, which allows a buyer of specific efficient equipment to pay off a no- or low-interest loan with the cost savings yielded from the monthly utility bill. Although financing solutions are not the domain of BTP, the department supports activities that remove barriers between efficient technologies and end-users. BTP could consider incorporating financing options into future knowledge sharing platforms to provide potential implementers with more information about these options.

- Improve downstream labeling - Labels provide consumers with information about energy use (e.g., the Federal Trade Commission's yellow EnergyGuide labels on energy-consuming products), operation and safety warnings, and other product details. Because no single rating protocol can give appropriate guidance for small, medium, and large customer classes and all climate zones, downstream labeling could be improved by reflecting some differences in regional or state energy costs, savings by climate type, and end-use applications. Water consumption associated with the devices would be useful to include as well. However, improvements to downstream labeling are the domain of regional, state, or even utility actors rather than DOE BT.

\footnotetext{
${ }^{33}$ Coalition for Energy Star Water Heaters: http://www.eswaterheaters.org
} 


\section{NAVIGANT}

\section{Appendix - Stakeholder Workshop}

On May $9^{\text {th }}$ and $10^{\text {th }}, 2011$, Navigant Consulting Inc., on behalf of the United States Department of Energy Building Technologies Program (DOE BT) and its Roadmap development team (Oak Ridge National Laboratory, ORNL, lead; Lawrence Berkeley National Laboratory, LBNL; National Renewable Energy Laboratory, NREL; and Pacific Northwest National Laboratory, PNNL), hosted a stakeholder workshop to identify water heating research, development, and demonstration (RD\&D) priorities as part of the development of the DOE's Water Heating Technologies RD\&D Roadmap.

The workshop was held in Berkeley, California, in conjunction with the annual Hot Water Forum hosted by the American Council for an Energy Efficient Economy (ACEEE). Ninety participants attended the workshop, including representatives from water heating equipment manufacturers, utilities, industry trade groups and organizations, government, DOE laboratories, and other research institutions. Table 9 presents a list of the attendees and their affiliations.

The objective of the workshop was to identify RD\&D priorities for consideration by DOE in the development of its Water Heating Technologies Roadmap. The Roadmap, to be completed by September, 2011, will provide guidance to the DOE in selecting water heating RD\&D projects for support in the next several years. The content of the workshop was organized into three major segments-equipment, distributing and using hot water, and policy and markets. After an introductory presentation for each segment, the participants joined smaller breakout groups for discussions of the RD\&D priorities in that segment.

During the discussions, attendees discussed opportunities for RD\&D in numerous areas related to water heating. At the end of the forum, each attendee was asked to identify and vote for ideas that should be prioritized; attendees were allotted three high priority votes and three medium priority votes. The results of the discussion and subsequent voting are presented in Table 10. The high priority votes were assigned a weighting that is double that of the medium priority votes. Representatives of DOE BT, Navigant, and the Roadmap team laboratories abstained from the voting process.

It should be noted that the final vote tallies noted in Table 10 are one element that the DOE will consider in making decisions regarding which topics to support, but they are not the sole criteria. Issues related to appropriateness of government support, fit with overall DOE BT priorities, and likelihood of technical and market success must also be considered.

Finally, Navigant, DOE BT, and the Roadmap development team wish to thank all the participants in this workshop. The suggestions, insights, and feedback provided during the forum are critically important for developing a useful Water Heating Technologies Roadmap.

Table 9. List of Workshop Attendees and Affiliations

\begin{tabular}{ll}
\hline Name & Affiliation \\
Water Heater Manufacturers: & \\
\hline Charles Adams & A.O. Smith Corporation \\
\hline Robert Heideman & A.O. Smith Corporation \\
\hline Stephen Memory & A.O. Smith Corporation \\
\hline Michael Parker & A.O. Smith Corporation \\
\hline
\end{tabular}




\begin{tabular}{|c|c|}
\hline Name & Afflliation \\
\hline Edmond Murray & Aztec Solar Inc. \\
\hline Eric Truskoski & Bradford White Corporation \\
\hline Andrew Tanner & Chromasun, Inc. \\
\hline Ram Narayanamurthy & EchoFirst Inc. \\
\hline Aaron Siegel & Eemax, Inc. \\
\hline Keith Burkhardt & General Electric Company \\
\hline Neil McDonald & General Electric Company \\
\hline Paul Home & Grand Hall USA \\
\hline Jason Sisler & Grand Hall USA \\
\hline Edwin Nordstrom & HTP, Inc. \\
\hline Kevin Pollard & Harsco Industrial Patterson-Kelley \\
\hline John Confrey & Noritz \\
\hline Josh Duckett & Noritz \\
\hline Seth Potkin & Noritz \\
\hline Joseph Boros & Rheem Water Heating \\
\hline Allen Wicher & Rheem Water Heating \\
\hline Hugh Magande & Rinnai Corporation \\
\hline James York & Rinnai Corporation \\
\hline Philippe Gregoire & Schüco USA \\
\hline Ronald Kraemer & Seisco International Limited, Inc. \\
\hline David Seitz & Seisco International Limited, Inc. \\
\hline Phil McConnell & Therma-Stor LLC \\
\hline Greg Gahagan & UMA Solar \\
\hline Erico Munhoz & Weil-McLain \\
\hline \multicolumn{2}{|l|}{ Other Manufacturers: } \\
\hline Larry Acker & Advanced Conservation Technology, Inc. Metlund Systems \\
\hline Sean Walker & Cerro Flow Products LLC \\
\hline Thomas Leck & E.I. du Pont de Nemours and Company \\
\hline Tom Buescher & Emerson Climate Technologies/White-Rodgers \\
\hline Gabriel Ayala & Enovative Kontrol Systems \\
\hline Cory Weiss & Field Controls, LLC \\
\hline Dale Drury & Grundfos Pumps Corporation \\
\hline Gerald Van Decker & RenewABILITY Energy Inc. \\
\hline Sid Abma & Sidel Systems USA Inc. \\
\hline Paul Steffes & Steffes Corporation \\
\hline \multicolumn{2}{|l|}{ Utilities: } \\
\hline Edgardo Joson & FortisBC Energy \\
\hline Dave Kresta & Northwest Energy Efficiency Alliance \\
\hline Robert Davis & Pacific Gas \& Electric Company \\
\hline Katrina Leni-Konig & Pacific Gas \& Electric Company \\
\hline Don Fisher & Pacific Gas \& Electric Company/Food Service Technology Center \\
\hline Cherif Youssef & Sempra Energy Utilities \\
\hline Steven Q. Ly & Southern California Gas Company \\
\hline Carlos Ruiz & Southern California Gas Company \\
\hline \multicolumn{2}{|c|}{ DOE National Laboratories } \\
\hline Tom Butcher & Brookhaven National Laboratory \\
\hline William Worek & Brookhaven National Laboratory \\
\hline Laura Draxler & Lawrence Berkeley National Laboratory \\
\hline Karina Garbesi & Lawrence Berkeley National Laboratory \\
\hline Alex Lekov & Lawrence Berkeley National Laboratory \\
\hline Jim Lutz & Lawrence Berkeley National Laboratory \\
\hline
\end{tabular}




\begin{tabular}{|c|c|}
\hline Name & Afflliation \\
\hline Chun-Chun Ni & Lawrence Berkeley National Laboratory \\
\hline Jay Burch & National Renewable Energy Laboratory \\
\hline Tim Merrigan & National Renewable Energy Laboratory \\
\hline Omar Abdelaziz & Oak Ridge National Laboratory \\
\hline Van Baxter & Oak Ridge National Laboratory \\
\hline Richard Murphy & Oak Ridge National Laboratory \\
\hline Srinivas Katipamula & Pacific Northwest National Laboratory \\
\hline Vrushali Mendon & Pacific Northwest National Laboratory \\
\hline \multicolumn{2}{|c|}{ Other Research Institutions: } \\
\hline Ammi Amarnath & Electric Power Research Institute \\
\hline Paul Glanville & Gas Technology Institute \\
\hline David Kalensky & Gas Technology Institute \\
\hline \multicolumn{2}{|l|}{ Government: } \\
\hline Sara Williams & Australian Department of Climate Change and Energy Efficiency \\
\hline Kacie Bedney & Bonneville Power Administration \\
\hline Chris Scruton & California Energy Commission \\
\hline Martin Thomas & Natural Resources Canada \\
\hline Joel Dickinson & Salt River Project \\
\hline Antonio Bouza & U.S. Department of Energy \\
\hline \multicolumn{2}{|c|}{ Industry Trade Groups and Organizations: } \\
\hline Harvey Sachs & American Council for an Energy-Efficient Economy \\
\hline Jacob Talbot & American Council for an Energy-Efficient Economy \\
\hline Linda Wigington & Affordable Comfort, Inc. \\
\hline Frank Stanonik & Air-Conditioning, Heating, and Refrigeration Institute \\
\hline Les Nelson & Solar Energy Industries Association \\
\hline \multicolumn{2}{|r|}{ 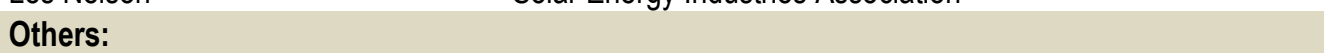 } \\
\hline \multicolumn{2}{|l|}{ Larry Weingarten } \\
\hline Gary Klein & Affiliated International Management, LLC \\
\hline Carl Hiller & Applied Energy Technology Company \\
\hline Nehemiah Stone & Benningfield Group Inc. \\
\hline Bill Jones & Blue Ocean Water Technologies \\
\hline Ben Schoenbauer & Center for Energy and Environment \\
\hline Craig Haglund & D\&R International, Ltd. \\
\hline Marc Hoeschele & Davis Energy Group, Inc. \\
\hline Larry Hales & Hales Global LLC \\
\hline Yanda Zhang & Heschong Mahone Group, Inc. \\
\hline Brad Bergling & ITT Corporation \\
\hline Claire Gagne & Navigant Consulting, Inc. \\
\hline William Goetzler & Navigant Consulting, Inc. \\
\hline David Grieshop & Reality LLC \\
\hline Michael Garrabrant & Stone Mountain Technologies, Inc. \\
\hline George Peterson & The Energy Center \\
\hline
\end{tabular}


Table 10. Ideas Proposed During Water Heating Workshop

\begin{tabular}{|c|c|c|c|c|c|}
\hline Topic & Code & Idea & $\begin{array}{l}\text { High } \\
\text { Priority }\end{array}$ & $\begin{array}{l}\text { Medium } \\
\text { Priority }\end{array}$ & Total $^{*}$ \\
\hline \multirow{22}{*}{ Equipment } & A.1 & $\begin{array}{l}\text { Combine with other technologies, e.g., micro CHP and renewables like } \\
\text { geothermal and solar }\end{array}$ & 17 & 6 & 40 \\
\hline & A.2 & $\begin{array}{l}\text { Cost effective high efficiency equipment (electric EF > 3.0; Gas EF > } \\
\text { 1.0; Gas powered high efficiency water heaters with } \mathrm{COP}>1 \text {; Reduce } \\
\text { stand-by losses) }\end{array}$ & 12 & 6 & 30 \\
\hline & A.3 & $\begin{array}{l}\text { Develop and demonstrate simple solar systems with low-cost and high } \\
\text { durability. Need solar water heating system component cost targets } \\
\text { (e.g., like PV and } \$ 1 / \text { Watt) }\end{array}$ & 10 & 8 & 28 \\
\hline & A.4 & $\begin{array}{l}\text { Develop aftermarket devices e.g., flue damper, condensing flue gas } \\
\text { recovery, etc. }\end{array}$ & 8 & 11 & 27 \\
\hline & A.5 & Demand response and integration with Smart Grid & 9 & 8 & 26 \\
\hline & A. 6 & $\begin{array}{l}\text { Study heat pump water heaters (effect on space conditioning: lab vs. } \\
\text { field, effect of climate/water temperature on performance). }\end{array}$ & 7 & 0 & 14 \\
\hline & A.7 & $\begin{array}{l}\text { Combination equipment designed for low space heating requirements } \\
\text { (e.g., where water heating is the primary use) }\end{array}$ & 3 & 1 & 7 \\
\hline & A.8 & New fluids for high temperature solar & 2 & 2 & 6 \\
\hline & A.9 & $\begin{array}{l}\text { Demonstrate the low cost of drain water heat recovery technology (in } \\
\text { single family and multifamily applications, horizontal, restaurant) }\end{array}$ & 2 & 1 & 5 \\
\hline & A.10 & $\begin{array}{l}\text { Improved pipes and fittings (e.g., insulated pipes, low loss fittings, heat } \\
\text { traps) }\end{array}$ & 1 & 3 & 5 \\
\hline & A.11 & Develop low cost solar for food service & 2 & 0 & 4 \\
\hline & A.12 & $\begin{array}{l}\text { Longevity research, durability tests (calcification, anode rods, scaling of } \\
\text { mixing valves) }\end{array}$ & 1 & 1 & 3 \\
\hline & A.13 & Retrofit recovery of $\mathrm{A} / \mathrm{C}$ or waste heat & 1 & 1 & 3 \\
\hline & A.14 & Develop improved working fluids for HPWH & 0 & 1 & 1 \\
\hline & A.15 & $\begin{array}{l}\text { Develop high efficiency atmospherically vented low NOx storage water } \\
\text { heaters }\end{array}$ & 0 & 1 & 1 \\
\hline & A.16 & $\begin{array}{l}\text { Learnable controls using artificial neural networks, where controls learn } \\
\text { use patterns and adjust set points }\end{array}$ & 0 & 1 & 1 \\
\hline & A.17 & Develop high R-value pipe insulation & 0 & 1 & 1 \\
\hline & A.18 & Thermometer for water heaters & 0 & 0 & 0 \\
\hline & A.19 & Hybrid platforms using multiple energy sources (electric and gas) & 0 & 0 & 0 \\
\hline & A.20 & $\begin{array}{l}\text { Retrofit technologies that fit in existing water heater footprint, especially } \\
\text { for existing small, single family }\end{array}$ & 0 & 0 & 0 \\
\hline & A.21 & Develop solar ready water heaters & 0 & 0 & 0 \\
\hline & A.22 & Direct contact gas (commercial laundries) & 0 & 0 & 0 \\
\hline Topic & Code & Idea & $\begin{array}{l}\text { High } \\
\text { Priority }\end{array}$ & $\begin{array}{l}\text { Medium } \\
\text { Priority }\end{array}$ & Total* $^{*}$ \\
\hline \multirow{10}{*}{ Distribution } & B.1 & $\begin{array}{l}\text { Develop data on behavioral patterns by household size, building } \\
\text { vintage, equipment type/age, etc. (efficiency vs. comfort) }\end{array}$ & 9 & 8 & 26 \\
\hline & B.2 & Collect field data on distribution systems layout & 11 & 3 & 25 \\
\hline & B.3 & $\begin{array}{l}\text { Develop improved analytical tools to model complete systems including } \\
\text { distribution of water heaters }\end{array}$ & 7 & 9 & 23 \\
\hline & B.4 & $\begin{array}{l}\text { Develop best practices by application and climate (SF, MF, non-res: } \\
\text { how do these work?, match application to tech., develop interactive } \\
\text { design guides) }\end{array}$ & 3 & 7 & 13 \\
\hline & B.5 & Develop low cost, simple monitoring equipment for various end-uses & 5 & 3 & 13 \\
\hline & B.6 & Promote transparency of total system performance metrics & 3 & 3 & 9 \\
\hline & B.7 & Study oversizing pipes/pumps (cost-benefit analysis) & 2 & 4 & 8 \\
\hline & B.8 & $\begin{array}{l}\text { Study trade-offs in different loss mechanisms (insulated pipes vs. low } \\
\text { flow fix) }\end{array}$ & 2 & 3 & 7 \\
\hline & B.9 & Smart grid-enabled building thermal system & 2 & 3 & 7 \\
\hline & B.10 & Incentivize correct installation and maintenance & 1 & 4 & 6 \\
\hline
\end{tabular}




\begin{tabular}{|c|c|c|c|c|c|}
\hline Topic & Code & Idea & $\begin{array}{l}\text { High } \\
\text { Priority }\end{array}$ & $\begin{array}{l}\text { Medium } \\
\text { Priority }\end{array}$ & Total $^{*}$ \\
\hline & B.11 & $\begin{array}{l}\text { Develop revolutionary approaches to hot water distribution (such as } \\
\text { being able to get hot water anywhere in the building in } 5 \mathrm{sec} \text {.) }\end{array}$ & 2 & 1 & 5 \\
\hline & B.12 & Develop "on-the-truck" selection tool for plumbers and contractors & 0 & 5 & 5 \\
\hline & B.13 & $\begin{array}{l}\text { Promote commissioning process for systems in large commercial } \\
\text { buildings }\end{array}$ & 2 & 1 & 5 \\
\hline & B.14 & Evaluate hot water "restorage" & 1 & 2 & 4 \\
\hline & B.15 & Determine effectiveness of "intelligent" controls & 0 & 3 & 3 \\
\hline & B.16 & Develop market specific system design tools & 1 & 1 & 3 \\
\hline & B.17 & Establish LEED credits for efficient distribution & 1 & 1 & 3 \\
\hline & B.18 & $\begin{array}{l}\text { Quantify second benefits of equal flow drain in water heat recovery and } \\
\text { capacity reduction (tank size) }\end{array}$ & 0 & 2 & 2 \\
\hline & B.19 & Outreach for building managers on proper design/operation & 1 & 0 & 2 \\
\hline & B. 20 & $\begin{array}{l}\text { Assess benefits of intelligent community-level reallocation of thermal } \\
\text { energy (for water heat) }\end{array}$ & 0 & 1 & 1 \\
\hline & B.21 & Best practice design guidelines for retrofit and new construction & 0 & 1 & 1 \\
\hline & B.22 & $\begin{array}{l}\text { Develop fixtures that make hot water less easily available (i.e., not the } \\
\text { default) }\end{array}$ & 0 & 0 & 0 \\
\hline & B.23 & Address health issues (e.g., legionella) & 0 & 0 & 0 \\
\hline & B.24 & $\begin{array}{l}\text { Study benefits of eliminating/adaptive controls recirc pumps, or using } \\
\text { zoning systems }\end{array}$ & 0 & 0 & 0 \\
\hline & B.25 & Evaluate losses from crossover "ghost" flow & 0 & 0 & 0 \\
\hline & B.26 & Use BIM capabilities & 0 & 0 & 0 \\
\hline & B.27 & Explore benefits of point-of-use design strategies & 0 & 0 & 0 \\
\hline & B.28 & Mandate embedded diagnostics for certain size/class (comm. only) & 0 & 0 & 0 \\
\hline & B.29 & Study what "good" means to users & 0 & 0 & 0 \\
\hline Topic & Code & Idea & $\begin{array}{l}\text { High } \\
\text { Priority }\end{array}$ & $\begin{array}{l}\text { Medium } \\
\text { Priority }\end{array}$ & Total $^{*}$ \\
\hline \multirow{19}{*}{$\begin{array}{l}\text { Policy \& } \\
\text { Markets }\end{array}$} & C.1 & $\begin{array}{l}\text { Energy Factor test improvements (climate specific, category specific, } \\
\text { add water waste/usage to test) }\end{array}$ & 10 & 9 & 29 \\
\hline & C.2 & Educate plumbers and contractors & 7 & 7 & 21 \\
\hline & C.3 & Better Federal coordination on water heater/systems (DOE \& EPA) & 5 & 9 & 19 \\
\hline & C.4 & Provide market for Renewable Energy Credits/Certificates & 7 & 4 & 18 \\
\hline & C.5 & CAFÉ-like standards for water heaters and "fleets" (eg. large chains) & 5 & 3 & 13 \\
\hline & C.6 & Demonstrate and publicize existing high efficiency technologies & 4 & 0 & 8 \\
\hline & C.7 & $\begin{array}{l}\text { System level standards (new construction to allow for solar thermal } \\
\text { ready systems, for example) }\end{array}$ & 2 & 4 & 8 \\
\hline & C.8 & Consider regionality in standards (cost of utilities, climate, etc.) & 4 & 0 & 8 \\
\hline & C.9 & $\begin{array}{l}\text { Thermal Metering Protocol/Standard (quantify the thermal energy } \\
\text { produced) }\end{array}$ & 2 & 2 & 6 \\
\hline & C.10 & On-bill financing & 1 & 4 & 6 \\
\hline & C.11 & Include drain water heat recovery in WH performance ratings & 2 & 2 & 6 \\
\hline & C.12 & Develop federal standards for solar water heating & 2 & 1 & 5 \\
\hline & C.13 & $\begin{array}{l}\text { Update plumbing codes and standards to accommodate lower flow } \\
\text { rates }\end{array}$ & 0 & 4 & 4 \\
\hline & C.14 & $\begin{array}{l}\text { Improve national/regional understanding of opportunities for specific } \\
\text { types of water heaters. (Study housing stock to understand optimum } \\
\text { applications of high efficiency equipment) }\end{array}$ & 2 & 0 & 4 \\
\hline & C.15 & Develop software and tools for homeowners & 1 & 2 & 4 \\
\hline & C.16 & Coordinate standards with Canada & 0 & 3 & 3 \\
\hline & C.17 & $\begin{array}{l}\text { Develop test procedure for point-of-use and booster water heaters ( } 2 \text { to } \\
20 \text { gallon) }\end{array}$ & 1 & 0 & 2 \\
\hline & C.18 & Physical demonstration of pipe diameters for plumbing codes & 1 & 0 & 2 \\
\hline & C.19 & $\begin{array}{l}\text { Require publication of physical parameters for benefit of modeling down } \\
\text { the road }\end{array}$ & 0 & 2 & 2 \\
\hline
\end{tabular}




\section{NAVIGANT}

\begin{tabular}{|c|c|c|c|c|c|}
\hline Topic & Code & Idea & $\begin{array}{l}\text { High } \\
\text { Priority }\end{array}$ & $\begin{array}{l}\text { Medium } \\
\text { Priority }\end{array}$ & Total $^{*}$ \\
\hline & C.20 & $\begin{array}{l}\text { Define and explore non-energy barriers to high efficiency water heater } \\
\text { models. Example: Noise (real or perceived) from heat pump water } \\
\text { heaters }\end{array}$ & 0 & 1 & 1 \\
\hline & C.21 & $\begin{array}{l}\text { Definition of hybrid water heaters (gray area of input Btu/hour and rating } \\
\text { method is not clear) }\end{array}$ & 0 & 1 & 1 \\
\hline & C.22 & Develop early adoption mechanisms for new high efficiency systems & 0 & 1 & 1 \\
\hline & C.23 & Simplify and ease waivers & 0 & 1 & 1 \\
\hline & C.24 & Develop standards for auditing methods and equipment performance & 0 & 0 & 0 \\
\hline & C.25 & Study on compliance and enforcement & 0 & 0 & 0 \\
\hline
\end{tabular}

